\title{
Social capital, conflict, and adaptive collaborative governance: exploring the dialectic
}

\author{
Cynthia McDougall ${ }^{1}$ and Mani Ram Banjade ${ }^{2}$
}

\begin{abstract}
Previously lineal and centralized natural resource management and development paradigms have shifted toward the recognition of complexity and dynamism of social-ecological systems, and toward more adaptive, decentralized, and collaborative models. However, certain messy and surprising dynamics remain under-recognized, including the inherent interplay between conflict, social capital, and governance. In this study we consider the dynamic intersections of these three often (seemingly) disparate phenomena. In particular, we consider the changes in social capital and conflict that accompanied a transition by local groups toward adaptive collaborative governance. The findings are drawn from multiyear research into community forestry in Nepal using comparative case studies. The study illustrates the complex, surprising, and dialectical relations among these three phenomena. Findings include: a demonstration of the pervasive nature of conflict and "dark side" of social capital; that collaborative efforts changed social capital, rather than simply enhancing it; and that conflict at varying scales ultimately had some constructive influences.
\end{abstract}

Key Words: adaptive collaborative governance; community forestry; conflict; equity; livelihoods; Nepal; participatory action research; social capital

\section{INTRODUCTION}

With the global population projected to reach 9 billion by the middle of this century (Godfray et al. 2010), the intertwined goals of sustainable natural resource management and human development pose challenges worldwide. Researchers and practitioners in natural resource management (NRM) and governance have begun to recognize the complexity and dynamism of the social-ecological systems involved in these challenges. Resource management and governance has been moving toward more adaptive, decentralized, and collaborative models (Armitage et al. 2007, Jiggins and Röling 2002).

Adaptive collaborative governance, based on social learning and inclusion, is one such approach. Social capital, or the "goodwill that is engendered by the fabric of social relations and that can be mobilized to facilitate action" (Adler and Kwon 2002:17), is significant to adaptive collaborative approaches in that it is posited as enabling the development of collaborative regimes (Plummer and FitzGibbon 2006), including community-based natural resource management (Pretty 2003, Bodin and Crona 2008). However, there is thus far relatively little literature relating social capital and adaptive collaborative approaches (Plummer and Fitzgibbon 2007). In this article, we apply social capital as a lens to shed light on some of the often overlooked, messy, and surprising dynamics and outcomes entwined in social-ecological systems, in particular, in relation to adaptive collaborative governance. Conflict is one such dynamic. Although the literature on conflict has grown over the past decades, conflict, and related power asymmetries, are neglected in adaptive governance (Vo $\beta$ and Bornemann 2011). Similarly, Sanginga et al. (2007) suggest that conflict is relatively little recognized in relation to social capital in NRM. The separation of these phenomena, i.e., conflict, social capital, and adaptive collaborative governance, creates several limitations and risks for policy and practice. Governance and management, including adaptive approaches, take place in "realworld political contexts that influence their functioning and impair their effectiveness" (Vo $\beta$ and Bornemann 2011:2). Lack of cognizance of social capital limits opportunities to build on existing strengths for learning or collaboration, such as networks. Lack of awareness of conflict, including power relations, contributes to the potential for policy or practice to marginalize or exacerbate the marginalization of more vulnerable subgroups of resourcedependent people (Vo $\beta$ and Bornemann 2011).

To address the above we focus on the dynamic intersections of social capital, conflict, and adaptive collaborative governance. In particular, we explore the complex and surprising dialectical relations among these phenomena at the local level in the context of community forestry. We do so by considering the changes in social capital and conflict that took place as 11 local community forest groups in Nepal shifted toward adaptive collaborative governance. Specifically, we explore the following questions: What was the nature of conflict in the sites at the outset of the research? Did conflict and social capital change as the groups shifted to adaptive collaborative governance, and if so, in what ways? Also, in what ways did adaptive collaborative governance, conflict, and social capital interact and influence one another?

\section{KEY CONCEPTS}

\section{Adaptive collaborative governance}

Adaptive collaborative governance has its roots in adaptive comanagement (Olsson et al. 2004, Colfer 2005, Armitage et al. 2007, Fisher et al. 2007), and draws on related fields including social, transformative, and organizational learning (Senge 1990, Argyris and Schön 1996, Mezirow 1997, Leeuwis and Pyburn 2002), community and participatory development (Chambers 1983, Barndt 1989), and community-based resource management (Leach et al. 1999, Kellert et al. 2000). The concept takes both the environmental and governance contexts, including the perceptions, knowledge, needs, and priorities of actors, to be diverse, complex, and dynamic. As such, previously-dominant lineal, top-down,

${ }^{1}$ Knowledge, Technology, and Innovation Group (KTI), Department of Social Sciences, Wageningen University, ${ }^{2}$ Center for International Forestry Research, Bogor, Indonesia 
command-and-control approaches are considered less appropriate to these contexts than learning-oriented, adaptive approaches that involve and connect stakeholders (Lee 1993, Leeuwis and Pyburn 2002, Berkes et al. 2003).

More specifically, adaptive collaborative governance can be defined as an approach in which groups of actors intentionally use social learning as the basis for decision making (see Leeuwis and Pyburn 2002), emphasize inclusion and equity in processes and outcomes, and seek to engender effective connections among actors and/or groups of actors (McDougall et al. 2013a, see also Olsson et al. 2006, Plummer et al. 2013). These parameters have implications in terms of the involved governance processes, arrangements, leadership, and facilitation. Specifically, they logically suggest that adaptive collaborative governance processes, norms, and arrangements need to be learning-oriented, and engender effective involvement and linkages, and that leadership and facilitation need to be enabling toward those ends. What these implications effectively mean in practice, however, needs further exploration and elucidation in the literature (Ojha et al. 2013, Plummer et al. 2013).

\section{Conflict}

Conflict over exhaustible resources is inherent in community-based natural resource situations (Cox et al. 2010, Gruber 2010), such as community forestry. Such conflict is recognized to lead to outcomes such as reduction in efficiency of resource management regimes, the possible collapse of initiatives, or even, in extreme cases, physical violence (Warner 2000). Yasmi et al. (2006:538) note that the literature examining why conflict arises commonly point to stakeholders' "differences or incompatibilities in interests, values, power, perception and goals." They further flag Glasl's (1999) observation that differences may be considered the basis for conflict, but "conflict only occurs if an actor feels "impairment" from the behavior of another actor due to these differences" (Yasmi et al. 2006:539).

The inherence of conflict in such natural resource contexts has suggested the need for the presence of conflict management mechanisms in such regimes (Ostrom 1990, Cox et al. 2010). In particular, studies underscore the need for such mechanisms to be accessible and low cost (Ostrom 1990, Cox et al. 2010).

\section{Social capital}

\section{What is social capital?}

The concept of social capital has multiple roots and varying definitions and usages, and has been applied to a range of social issues in a number of fields, including to participatory and rural development (Uphoff 2000, Uphoff and Wijayaratna 2000) and to problems of collective action (Ostrom and Ahn 2008). As introduced above, the concept of social capital can be understood, in broad terms, to refer to "the goodwill that is engendered by the fabric of social relations and that can be mobilized to facilitate action" (Adler and Kwon 2002:17). The concept draws attention to the value of social ties and bonds (Pretty and Ward 2001) through its recurring themes, which include norms, rules, trust, and networks (Putnam 1993, Pretty and Smith 2004, Ostrom and Ahn 2008). Given its wide usage and evolving nature, the concept has multiple points of possible divergence and contradiction, and these influence its application and use as an analytical lens. Taking the above broad definition as a starting point, we consider the following three conceptual nuances for the purpose of this study.
First, although some conceptualizations of social capital focus on it as a resource that may be embodied in or held by groups, others expand to include social capital as a resource held by individuals. For example, Putnam's widely known framing of social capital in terms of "the features of social organization, such as trust, norms, and networks that can improve that efficiency of society by facilitating coordinated actions" (Putnam 1993:167) implies the former. For the purpose of this study, we embrace Adler and Kwon's (2002) more encompassing framing of the concept as a resource "available to individuals or groups" (2002:23).

A second nuance relates to the inter-related notions of scale and boundaries. Social capital can be explored and understood at a range of scales from micro through to macroscales (Lyon 2000). Moreover, the focus can be within a group or internal ("bonding" social capital), or it can be on horizontal or vertical connections of an actor or groups with actors or groups external to them ("bridging" and "linking" social capital, respectively; see Patulny and Svendsen 2007, Pretty and Smith 2004). In this study we follow Adler and Kwon (2002:21) in noting that the "distinction between the internal and external views is ... a matter of perspective and unit of analysis. ... Moreover the views are not mutually exclusive." As such, in this study we take a "nested" approach, considering groups (community forestry user groups), and subgroups within these, as well as linkages to actors outside of both of these.

Finally, a third and related nuance is the analytical focus. We follow Adler and Kwon (2002) in addressing both structural aspects, such as groups and networks, as well as content-related aspects, such as norms, rules, and shared understanding. Plummer and Fitzgibbon (2007) similarly recognize "objective" or "structural" and "subjective" or "experiential" aspects, while Uphoff (2000) and Krishna (2007) frame them in terms of "structural" and "cognitive" aspects.

\section{Effects of social capital}

As expressed by Coleman (1988:S98) "social capital is defined by its function." Social capital facilitates actions and is productive, "making possible the achievement of certain ends that in its absence would not be possible" (Coleman 1988:S98). This is framed in different ways, including social capital as facilitating "coordination and cooperation for mutual benefit"(Putnam 1998:236), enhancing actors' "ability to solve collective-action problems" (Ostrom and Ahn 2008:20), or increasing "the amount (or probability) of mutually beneficial cooperative behavior” (Uphoff 2000:216).

Despite these positive effects, there are some justified caveats regarding social capital. Ostrom (1999) and Ballet et al. (2007) have noted that although the concept is framed largely in positive terms, it also has a "dark side" (Ostrom 1999:176). For instance, R. Bolton (2005, unpublished manuscript:24) notes that "tight bonds and group loyalties may accentuate negative features of the groups' antisocial behavior, insularity, exclusionary practices, inhibition of initiative." Such bonds may limit innovation (Ballet et al. 2007). In this study, we observe and discuss both potential positive and negative effects.

\section{Sources and formation}

Despite its popularity as a concept, more needs to be done to elucidate the formation and sources of social capital (Adler and Kwon 2002, Krishna 2007). In line with its overall conceptual complexities, social capital formulation reflects a chicken-and-egg 
dilemma (Krishna 2007, Plummer and Fitzgibbon 2007), which we take to suggest the need for a nonlinear approach to its understanding.

In line with the above conceptual nuances, we follow Adler and Kwon (2002) in considering the potential role of both structural and content aspects of relations in creating social capital. Networks of social ties, for example, generate opportunities for social capital transactions, although these ties may differ in terms of frequency, intensity, and other factors (Adler and Kwon 2002). Such social linkages give actors the opportunity to leverage others' resources, including information, and create opportunities to act together (Coleman 1988, Adler and Kwon 2002). Content aspects, such as norms, rules, and trust, may play a motivational role in developing social capital (Adler and Kwon 2002). Not all rules and shared norms, however, are likely to contribute to social capital, a point which is implied in Putnam's emphasis on norms whose content contributes directly to trust (Adler and Kwon 2002, Ostrom and Ahn 2008).

Krishna (2007) usefully grounds the question of purposive social capital formulation in the community development context. In doing so, he assesses the influence of factors both within and outside of the groups of interest. Our study similarly reflects a consideration of both internal and external influences, as it explores how social capital, and conflict, change in and through multidirectional interaction with each other and with adaptive collaborative governance.

\section{METHODOLOGY}

\section{Research design and analysis}

The study reported here is based on comparison across multiple indepth, multiyear case studies (Yin 2009). Four case studies ("longterm sites") were developed in the first phase (1999 - 2002); an additional seven ("short-term sites") were added in the second phase (2004 - 2007). In 2008 the research team conducted a final field visit to each site $(n=11)$. All of the case studies were community forest user groups (CFUGs).

The research design created the opportunity to investigate both the catalyzation and development of adaptive collaborative governance and its outcomes at the local level, i.e., with CFUGs. The study thus combined participatory action research (PAR) with qualitative and quantitative social science assessment. PAR is an established participant-centered methodology that both generates knowledge and catalyzes social change (Lilja and Ashby 2000, Fisher et al. 2007), and seeks to empower research subjects as partners of the knowledge generation processes (Fals-Borda and Rahman 1991). The PAR enabled the catalyzation and development of the adaptive collaborative innovations in governance (processes, arrangements, facilitation, and leadership), while the social science assessments generated baseline and longitudinal data.

In each of the two study phases, the research began at each site with background studies conducted by the researchers, then transitioned to PAR, had interim assessments at the midpoint, and concluded with a round of final assessments. The PAR involved each CFUG, together with researchers and facilitators, developing and applying innovations in governance (processes, arrangements, leadership, and facilitation) as a means of better achieving its goals. In particular, the innovations were intended to make governance more inclusive and learning-based, i.e., to support the CFUGs in developing and applying an adaptive and collaborative approach to governance. The PAR-based innovations were sparked initially through discussion among CFUG leadership, members, researchers, and facilitators and through visioning and selfmonitoring workshops in each site. Cycles of visioning and selfmonitoring, and resulting adjustments of CFUG strategies, plans, activities, rules, or ways of operating, then continued to be carried out by the CFUGs in conjunction with and supported by facilitators, with periodic input by researchers during site visits. The innovation process was emergent in nature, with the CFUGs' ongoing learning shaping the innovations, strategies, and outcomes that developed.

The PAR was facilitated in the first phase by researchers (for 13-16 months), accompanied by effort to hand over to local facilitators by the end of Phase I. Throughout Phase II, facilitation was provided (for approximately 19 months) by teams of 2-4 local (CFUG) and meso actors in each site, drawn from community forestry networks, nongovernmental organizations, bilateral agencies, or district forest offices. The facilitators were women and men from a range of socioeconomic backgrounds who were selected according to suggestions of community and district actors, based on agreed criteria, such as commitment to equity, ability to commit the time required, and potential to be accepted in the role by diverse local actors. The facilitators were trained and backstopped by the researchers; the teams of facilitators also periodically networked with each other through reflection workshops and study tours.

The background, interim, and final assessments involved gathering sets of comparable socioeconomic and institutional information to enable before-and-after analysis and analysis across sites. For the purpose of this study, as well as changes in governance, the information gathered centered on changes over time in external forces (conditions or influences), internal and external relations (including conflict), as well as norms, decisions, rules, and practice (including distributional equity). Socioeconomic and institutional data were collected through participant observation of formal and informal processes and occurrences, participatory wealth ranking (using each site's own criteria), focus group discussions, participatory mapping (Colfer et al. 1999a, $b$ ), document reviews, and ongoing field recording, as well as in some sites, Social Systems Analysis tools (http://www.sas2.net/tools/). Document reviews were of CFUG materials (committee records, assembly meeting minutes, Operational Plans, self-monitoring records of CFUGs) to source and validate data such as formal group decisions and plans, activities, self-monitoring assessments, and subgroup formation. Data regarding perceptions of distributional equity were gathered through participatory pebble distribution exercises at each site (based on Colfer et al. 1999a). Participatory methods, including pebble distribution, were carried out separately in terms of gender, wealth, and/or interest groups as appropriate, such as women and men, Dalits ${ }^{[1]}$ and non-Dalits, poor and nonpoor members, and executive and nonexecutive members. Data were triangulated through the use of multiple sources as well as multiple methods, including through cross-checking with CFUG members and through field observations.

The central analytic approach was the iterative examination of the observed and documented changes and influences to seek "plausible causal connections" between them (Fisher et al. 2007). A key feature was the iteration between in-depth field experience 
and analysis. The research team identified and repeatedly assessed emergent themes and patterns in the material across cases (Patton 2003, Yin 2009). This included searching for exceptions (negative or deviant cases) and "surprises" in the material (Patton 2003). Data were compiled and analyzed across sites by gender and by locally identified wealth groups (rich, medium, poor), as well as by other relevant groupings as appropriate, such as executive committee and nonexecutive committee members. Quantitative data were analyzed using descriptive statistics through comparison of "pre-" and "with" periods data using Excel (Microsoft 2007). Following Yin (2009), the combination of in-depth case experience with comparison across cases contributes to the robustness of the study.

\section{Sites}

Nepal was selected for the research because of its well-established community forestry program, which assigns formal management and use rights to designated CFUGs. For the purposes of rigour through regional diversity of the comparative cases, and based on the recommendations of national stakeholders, the sites were based in the districts of Kaski, Sankhuwasabha, Palpa, Nawalparasi, Lalitpur, Dhankuta, and Morang. The districts and thus sites spread from east to midwest and from the southern plains (Terai) to the mid-Hills area. The far-western region was avoided for safety reasons relating to the Maoist insurgency (see Appendix 1). During the course of the research, the conflict extended across the country and influenced all sites, with the long-term sites being the most significantly affected.

Selection of the sites (CFUGs) involved consultation with districtlevel stakeholders and field assessments of potential sites. The sites were selected for being average (i.e., "normal," or not already highly innovative or successful) for their districts, based on the criteria of: governance (processes, arrangements, and leadership), activeness (regularity of meetings and activities), internal and external relationships, occurrences of conflicts (within the group and with external actors), and success in implementing activities and achieving goals.

Although fitting the above criteria, together the sites offered variation across groups in terms of group size, and within groups in terms of socioeconomic diversity. The number of households per CFUG ranged from 111 to 751 (with a median value of 156). All sites were socially heterogeneous, comprising from 5 to 12 ethnic and/or caste groups. Based on each CFUG's own criteria, participatory wealth ranking exercises indicated that across all research sites approximately $11 \%$ of member households were considered to fall in the "rich" category, 52\% in the "medium" category, and $37 \%$ in the "poor" category.

\section{Analytical framework}

In framing changes in governance, we focus on processes, arrangements, leadership, and facilitation. In particular, within these we consider aspects flagged as relevant to adaptive collaborative governance (key concepts), namely learningorientation, involvement (inclusiveness) and linkages, and enabling roles.

In framing of changes in social capital we draw on Adler and Kwon's (2002:23) working definition, which highlights that "[social capital's] source lies in the structure and content of the actor's social relations. Its effects flow from the information, influence and solidarity it makes available to the actor." Drawing also on Pretty and Ward (2001) and Nath et al. (2010), we thus focus on three aspects, each represented by a set of proxies: structural (groups, networks); content (group orientation, rules, and norms); and effects (information sharing, equity and inclusion, collaborative activities, and joint actions). For the nonstructural aspects, proxies are utilized because of the challenges inherent in measuring social capital (Plummer and FitzGibbon 2006). The specific proxies are selected to be context-appropriate, which is important for relevance (Krishna 2007). Thus in addressing content, we focus on group orientation (conservation versus subsistence and/or income) and propoor rules and norms because they reflect norms and rules relating to cooperation for mutual benefit and trust, and because they address to issues of forest benefits and equity, which are central challenges in the Nepal community forestry context (Kanel and Dahal 2008). Similarly, in measuring changes in terms of effects, as well as considering "information sharing" (as per Adler and Kwon's 2002 definition), we consider changes in perceptions of distributional equity and inclusion, collaborative activities, and joint actions. As indicators these are highly contextually relevant, as well as reflecting the beneficial end goal aspects of social capital as per Coleman (1988), Putnam (1998), and Uphoff (2000). Moreover, within the measurement of perceptions of distributional equity, changes in the degree to which group member perceptions are shared, corresponds to "shared understanding" as an indicator of social capital (Plummer and Fitzgibbon 2007).

In presenting conflict, we focus on conflict that arose within the local level, but also touch on meso-related (up to the district level) conflicts, and the influence of national scale conflict (the Maoist insurgency). When we describe observed changes in conflict, we are referring to observed changes in tensions (such as complaints and arguments), as well as to the establishment of alternative strategies, including adjustments and compromises in processes, decisions, or distributional outcomes.

\section{RESULTS}

\section{CFUG conflicts at the outset}

The early rounds of research revealed that all the CFUGs had some form of conflict at the start of this study, most of which had persisted over many years. Three CFUGs had multiple ongoing conflicts. The issues around which the more explicit intra-CFUG tensions or conflicts revolved are as follows; for clarity, based on our field experiences, we group them into three categories:

\section{Power and access to decision making:}

- control over/inclusion in the CFUG, including class, caste or gender conflict (3 sites);

- corruption and transparency issues/low trust of members toward the executive committee ( 2 sites); and

- political party rivalries (1 site).

2. Rights and resources (distributional equity):

- forest product distribution/benefit sharing (4 sites);

- "illegal" collection and sale of firewood by daure (firewood sellers; 1 site); and

- boundary/encroachment issues (4 sites). 
Table 1. Governance processes, arrangements, and leadership roles: comparing pre- and with adaptive collaborative approach $(\mathrm{n}=11)$. Notes: The "Before" data are from the preadaptive collaborative governance period (1999 in the long-term sites and 2004 in the short term sites); the "After" data are from the "with" period (2006/2007 in all sites). CFU G =community forest user group. Sources: key informant interviews, observation, review of CFUG meeting records, background study, and final assessment reports.

\begin{tabular}{|c|c|c|c|c|}
\hline \multirow{2}{*}{$\begin{array}{l}\text { Processes, } \\
\text { arrangements, } \\
\& \text { roles }\end{array}$} & \multicolumn{2}{|c|}{$\begin{array}{c}\text { Prior to adaptive collaborative governance } \\
\text { ("Before") }\end{array}$} & \multicolumn{2}{|c|}{$\begin{array}{l}\text { With adaptive collaborative governance } \\
\text { ("After") }\end{array}$} \\
\hline & Key characteristics & Specifics & Key characteristics & Specifics \\
\hline $\begin{array}{l}\text { Planning \& } \\
\text { decision- } \\
\text { making }\end{array}$ & $\begin{array}{l}\text { Linear or ad hoc } \\
\text { in nature with little } \\
\text { reflection or link }\end{array}$ & $\begin{array}{l}\text { Plans developed from standard area } \\
\text { "blueprints" or from leaders' at-the- } \\
\text { time interests. }\end{array}$ & $\begin{array}{l}\text { Planning based in } \\
\text { social learning }\end{array}$ & $\begin{array}{l}\text { CFUG goals based on an explicit shared } \\
\text { vision. }\end{array}$ \\
\hline
\end{tabular}

processes to goals

Decisions generally taken by chairperson or one or two members.

Institutional Hierarchical arrangements structure (structures)

\begin{abstract}
Executive committee (central decisionmaking body).

General assembly, primarily for informing members and formalizing decisions taken by the committee; sometimes also forum for argument regarding decisions.
\end{abstract}

"Nested decision making" based on linked nodes

\author{
Planning through CFUG self-monitoring, \\ including tracking equity. \\ CFUG processes, including planning by \\ action groups, involved regular reflection and \\ other learning tools (e.g., trial plots, \\ experiments, analysis of risk, and \\ uncertainty). \\ Process design, active facilitation and \\ encouragement of shared learning to \\ encourage participation of marginalized \\ members and build understanding across \\ subgroups. \\ Ongoing two-way communication between \\ executive committee and toles (hamlet). \\ Tole meetings; the basis for planning and \\ decision making and forum for direct member \\ input. \\ Executive committees, working routinely with \\ toles through joint meeting of tole \\ representatives and executive committee.
}

General assemblies, the final step in decision making and for additional information sharing.

Action groups, the hubs of leadership and implementation for each activity (e.g., incomegeneration group, equitable forest product distribution committee, etc.).

Decisions taken by executive committee, in particular, by the chairperson.

Top-down and delegated (decisions made on behalf of members).
Shared and distributed leadership
Leadership shared among tole, executive committee and action group leaders; process leadership by facilitators.

Oriented toward communication, enabling input and integration of members' views and priorities.
3. Noncommunity forestry related conflicts:

- disputes between members about noncommunity forestry issues ( 1 site); and

- rivalry between ethnic groups (1 site).

\section{Changes in governance}

Several governance-related patterns emerged across the sites that illustrate the shift to adaptive collaborative governance. We present these here in terms of process, arrangements, and leadership and facilitation roles (Table 1; see also McDougall et al. 2013b). These shifts were sparked and supported through the PAR. This involved being catalyzed initially through discussions between CFUG members, facilitators, and researchers, subsequently through community-based visioning and selfmonitoring process development workshops at each site, and then supported in an open-ended way through ongoing encouragement and facilitation at each site by facilitators and, periodically, researchers. Contextual and internal feedback influences relating to these changes in governance are presented in an integrative manner (see also McDougall et al. 2013b).

Process

During the PAR the CFUGs adjusted their long-term and annual decision-making processes to become more learning-oriented and inclusive (Table 1). Specifically, the CFUGs began to routinize participatory planning based on cycles of shared visioning, self- 
monitoring, reflection, and iterative redesign, adjustment, and implementation of their plans. The agreed vision for each CFUG was developed initially through a CFUG workshop and revisited semiannually or annually by each CFUG. All CFUGs used their respective visions as the basis to identify indicators by which they could monitor their own progress. The ongoing cycles of selfmonitoring involved shared, bottom-up assessment by CFUG members of strengths and weaknesses in their own CFUG, with reference to these indicators. This was generally done annually or semiannually, using a pictorial representation of success (generally five scoring options represented by a full to new moon), and discussion of factors and possible ways to improve. The selfmonitoring covered all aspects of each CFUG's own vision, including aspects relating to governance, internal equity, information sharing, and external relations. To support in selfmonitoring equity, the CFUGs undertook what we refer to as "equity-tracking." This involved the CFUGs using their own participatory wealth ranking and other data to monitor the relative access of members from different wealth groups to CFUG positions, benefits, and opportunities. The learning from the selfmonitoring, including governance and equity-related, was applied by each CFUG to adjust its strategies, including rules, activities, decisions regarding distribution or access to opportunities, plans to link to external organizations, or even to the decision-making processes or arrangements themselves.

\section{Arrangements}

Decision-making arrangements in the CFUGs shifted from centralized decision making by executive committees toward nested, i.e., multi-level, multi-node, and interconnected, arrangements (Table 1). The CFUGs began to use toles (hamlets) as the primary nodes for discussion and reflection in recognition of tensions relating to power and access to decision making, and weaknesses in information flow. Tole members began to meet regularly, monthly or as needed, to share information and/or address conflict. Toles also became the starting point for bottomup self-monitoring processes, meeting every six months or as decided to undertake the visioning and self-monitoring processes, considering indicators to spark reflection on strengths and weaknesses and to draft and revise priorities and strategies. A new, routinized linkage between the toles and the executive committees was used for negotiating and integrating ideas and priorities from all toles. General assemblies became the final phase in a process in which members were involved, via the tole discussions, rather than a forum at which they were informed about and asked to endorse, or tried to contest, committee decisions. Volunteer action groups also emerged as nodes of local decision making and action, such as women's groups selling forest products or (mixed) groups overseeing equitable forest product distribution or monitoring CFUG loans. These emerged from the revised decision-making processes, and were connected to the CFUGs through the general assemblies and the committees.

\section{Leadership and facilitation}

With the transition to adaptive collaborative governance, leadership roles expanded from a delegative, centralized mode, in which the executive committee acted on behalf of others, to a distributed leadership mode, with members at the level of toles or action groups providing leadership, as well as facilitators. The facilitators purposively engaged in a proinclusion approach to facilitation, in other words, they consciously sought to enable the engagement of previously marginalized members. Specifically, they sought to enable a more socially accessible and nonthreatening decision-making space through means such as actively inviting input from and recognizing the contributions of the women, the poor, and Dalit members, and by recognizing and strategically addressing disagreements. Moreover, the facilitators, and the invited outside actors, frequently offered critical questions regarding equity in the CFUGs as a means of encouraging members to recognize their previously unacknowledged assumptions and views, for example about gender, wealth, or caste and entitlements.

The growing pool of trained facilitators and the researchers also encouraged CFUG members to adopt and routinize a "learning approach." As such they encouraged the CFUGs to approach each process and activity as an experiment and an opportunity to learn and improve. They supported learning by coaching the CFUGs to routinely reflect on their own planning and decisionmaking practices and their consequences. Such routinization is illustrated by the facilitators and CFUG members' starting to commonly use the phrase "pharkera herne" ("looking back") as both a regular expression and a general process guideline in their discussions. Further, an example from one site illustrates the reflective approach to process. This CFUG had tried selfmonitoring prior to the study but had abandoned this practice because the members had found it unhelpful. Early in the PAR, the facilitators encouraged the members to analyze and discuss their self-monitoring experience and outcomes. The group realized that it had approached self-monitoring as if it were an external competition or posed a risk to the CFUG in terms of possible retribution by the district forest office if they showed weaknesses. They had thus given themselves exaggeratedly positive scores. The members also perceived their procedures to have been rushed and to have had limited participation. They subsequently chose to begin a process of more realistic group selfassessment to identify their (actual) strengths and weaknesses as part of the development of plans.

\section{Changes in social capital}

We present the social capital-related findings in 3 subsections: structural (groups, networks); content (CFUG orientation and propoor rules and norms); and effects (information sharing, influence and solidarity). In each of these, we present data regarding changes and briefly note observed factors in, and consequences of, these changes.

\section{Structure: groups and networks}

The changes in governance outlined above were coupled with changes in groups (composition, numbers) and networking. Each CFUG continued to have one group, an executive committee, that played a central role in its governance, but with the shift to adaptive collaborative governance the composition of these executive committees changed in terms of the representation of women and poor members. Composition is significant here in that it reflects the growing involvement of a greater diversity of members, including marginalized ones, in the formal decisionmaking centers of the CFUGs. The representation of women in the executive committees (averaged across all sites) approximately doubled, from $18 \%$ to $34 \%$ between the pre- and with-adaptive collaborative governance periods. Among female representatives, poor women made the largest percentage gain, from $31 \%$ to $40 \%$. 
In terms of wealth groups, the representation of people on the executive committee considered by their CFUGs to be poor, comprising roughly $37 \%$ across all CFUGs, increased from $15 \%$ to $29 \%$.

Over the same period, at each site the number of internal groups increased. Specifically, while some CFUGs formally had tole (hamlet) divisions, they were not actively used as forums for information sharing, problem solving or decision making. With adaptive collaborative governance, all the CFUGs created and/ or activated toles as nodes of communication and governance. These tole-level groups were small and relatively geographically and socially accessible for members, including marginalized ones. They were also directly linked to the executive committees through tole-executive meetings. Through these, CFUG members came to have direct access to an effectively connected subgroup within the formal structures of the CFUG. Additionally, with adaptive collaborative governance each CFUG developed multiple action groups to lead its initiatives. As with toles, the action groups were connected to other decision-making nodes through routinized meetings, exchanges, and joint decision making (Fig. 1).

In terms of external linkages, prior to the shift to adaptive collaborative governance, the CFUGs' networking activities were limited. All CFUGs had a formal connection to the district forest office in relation to the required approval of their 5-10 year Operational Plans; several sites had been somewhat involved with a national community forestry network, or with nongovernmental or bilateral development organizations for advocacy, training, or technical and institutional support. In some cases, the CFUG had become part of a meso level network of CFUGs; members reported, however, that there was little meaningful sharing or learning among the network.

In the course of the PAR the CFUGs became more aware of the potential of networking (see Appendix 2.1). As PAR progressed, the CFUGs became more proactive in building networks and in collaborating with other actors, both horizontally (with other CFUGs) and vertically (with meso actors). Specifically, once the CFUGs had identified their own needs, they began to take steps to access additional information or resources, or to develop partnerships with external agencies, which they had not done previously. For example, the CFUGs in three sites each formed teams to investigate options for accessing markets, technical information, or financial support. These teams strategically visited appropriate organizations to discuss potential partnerships. In another site, the CFUG took the initiative to jointly reflect on a past failed partnership with a nongovernmental organization, and to jointly replan this relationship to avoid past mistakes. Across sites, the main forms of networking and collaborating became:

- Increasing collaboration with local (community) institutions;

- CFUG-CFUG sharing;

- New involvement in meso (district or subdistrict) CFUG networks or forums, and, in one case, a multi-CFUG commercial enterprise (nontimber forest product enterprise);

- Proactive expression of needs for information, resources, or collaboration to outside agencies, and more regularly inviting outside actors to participate in or facilitate CFUG processes.
Fig. 1. (a). Flowchart of internal structural relations (groups) preadaptive collaborative governance. Notes: EC = executive committee. The executive committee was the only formal decision-making group in the community forest user groups (CFUG). It communicated largely in a unidirectional manner with members, mainly via the annual general assembly (in some sites the assembly was not held at all). (b). Flowchart of internal structural relations (groups) with adaptive collaborative governance. Notes: $\mathrm{T}=$ tole (hamlet); $\mathrm{ag}=$ action group, for example women's savings group, bamboo handicraft production and sales group, forest encroachment monitoring committee, loan monitoring committee. The toles, led by tole committees and representatives, had direct input to CFUG annual planning and decisions and direct access to executive committee information through routinized executive committee-tole representatives meetings and negotiations, i.e., two-way communication. Action groups emerged mainly from the annual planning process to lead CFUG initiatives and engaged in two-way communication with executive committees and general assemblies, as well as with toles, as needed.

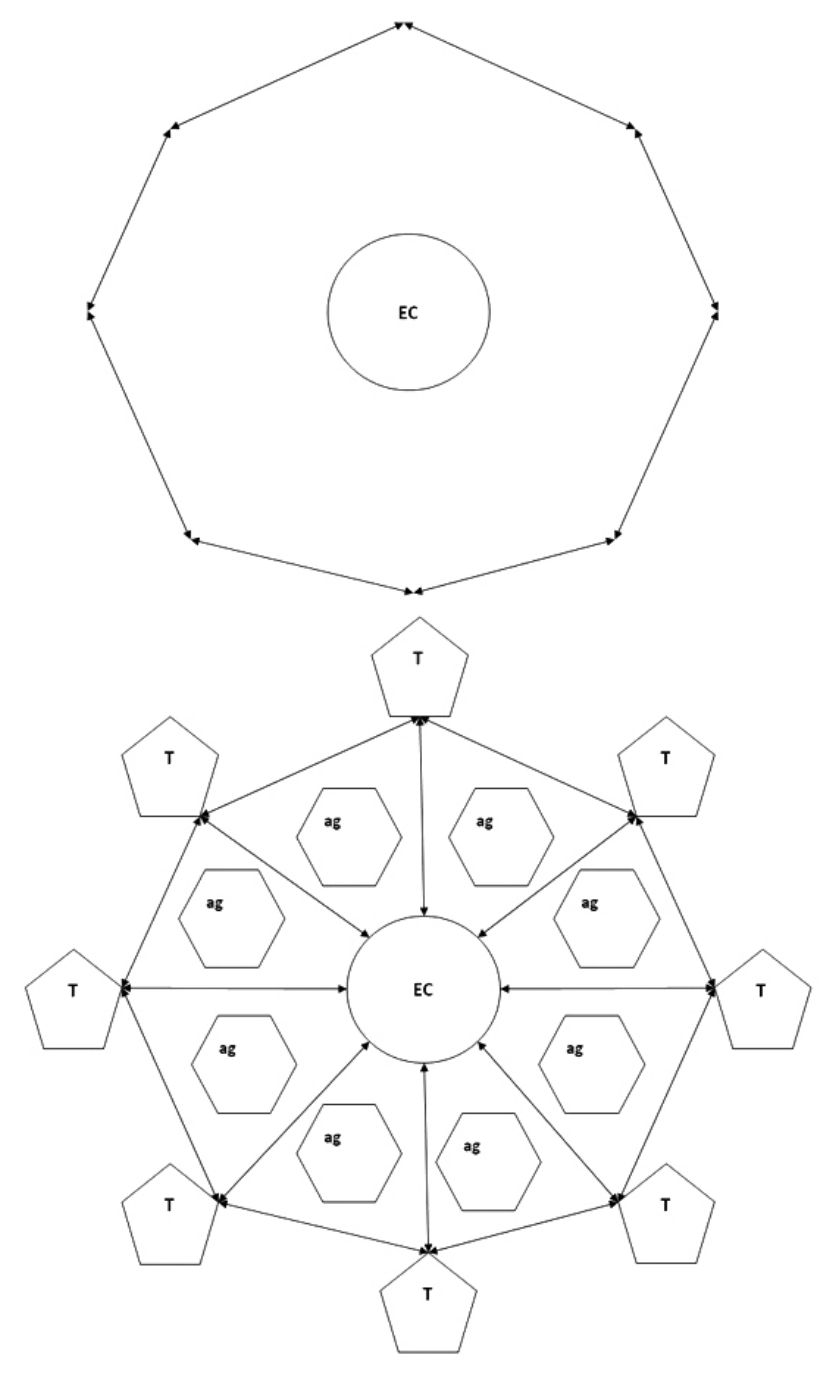


The increase in interorganizational connectivity and in relations with external agencies is also evidenced by the CFUGs' selfmonitoring, in particular, by the assessment of indicators relating to such external relationships. As outlined above, these selfmonitoring systems were the basis for the CFUGs' learningoriented governance processes, and the indicators were developed by each CFUG based on their own CFUG vision. The CFUGs created and monitored a total of 23 such indicators relating to external relationships; 20 of these indicators improved and 3 (all at one short-term site) stayed the same over the research period.

We note in addition, in terms of external linkages, that the CFUGs were at some point all exposed to the Maoist insurgency and broader civil movement's proequity discourse, through word-ofmouth, various media, or direct interaction with Maoists and exposure to their educational speeches. Also, the Maoist insurgency affected the stability and quality of the CFUGs' external connections and access to services, especially those provided by the government. District forest offices' activities and support were interrupted. For example, in one district that was home to two sites, six of the eight range post offices were closed and the local government office ceased to function. The range post responsible for one site was burned down. One ranger was assaulted; other forest office staff reportedly did not visit CFUGs in some areas of their district for nearly a decade. In response to the decline in meso services, in two of the sites the facilitators worked with CFUGs to catalyze the development of two active CFUG networks between 2005 and 2006, even in the absence of government-related actors. Despite the absence of active range post offices, within these networks many CFUGs still planned and implemented collaborative activities such as silviculture, road construction, and the investment of CFUG funds, as well as continuing to promote learning and sharing among network members.

One key observed consequence of the overall changes in networking was that greater involvement with meso actors often meant increased CFUG exposure to proequity ideas and values, resources, and support for propoor and prowomen changes. This raised awareness of equity issues and options for change, helped motivate marginalized members to raise their concerns and demands, and likely increased the pressures on dominant actors to be more inclusive. The Maoist insurgency contributed to this pressure in an evident, albeit tragic, way at one site, where the CFUG chairperson was attacked by Maoists and hospitalized. There were also documented changes in some meso actors regarding their attitude toward marginalized members over the research period. For instance, one forest officer said: "It seems that we can conserve the forest through Daure [firewood sellers] at the same time giving them opportunity of making a living from it. When we started discussing with them regularly we came to know that they were ready to change their livelihood strategy if forest destruction was caused by them. When they are included in the CFUG process, they are receiving the same level of benefits as before, or even more, and surprisingly, the forest is growing. We were wrong in the past for blaming Daure for destruction of forest" (male, District Forest Office staff person).

Content: CFUG orientation and propoor rules and norms Prior to adaptive collaborative governance, the CFUGs were oriented mainly toward conservation (Fig. 2). This orientation reflected the conservation-based interests of the forest offices and elite members, while excluding other management purposes and forms of activity such as livelihood activities that aligned with the priorities of the poorer members. The former chairperson of one site had asserted: "We should stop any kind of business from the forest, not to sell firewood, timber, or anything else..." With adaptive collaborative governance, the CFUGs began to accept a wider range of purposes and activities (Fig. 2), including meeting subsistence needs, and income generation. Interestingly, the CFUGs at the same time became more active in their conservation and protection measures, for example by developing rotating "forest watcher" systems, hiring forest guards, and/or enforcing rules.

Fig. 2. Changes in CFUG orientation: bomparing pre- and with-adaptive collaborative governance $(n=11)$. Notes: $\mathrm{ACG}=$ adaptive collaborative governance; Pre-ACG $=2000$ in the long-term sites and 2004 in the short-term sites; With ACG = 2006 in all sites; $\mathrm{CF}=$ community forest $\mathrm{CFUG}=$ community forest user group. Examples of the emerging mixed orientation include: one site divided its forest blocks (one protected, one for income generation via coffee, and two for subsistence use of fuelwood, timber, and grass for goat-raising by poor households); another site started patrolling community forest areas to control illegal extraction of nontimber forest products while also beginning income generation through allo (Girandinia diversifolia) and lokta (Daphne) collection; a different site continued to prioritize protection because of its young forest (and so reduced timber extraction), while also adding income generation for the poor through fuelwood selling. Sources: CFUG record review (Constitution, Operational Plan, annual plans, meeting minutes), key informant interviews, observation of CFUG meetings and forest management implementation, forest walks.

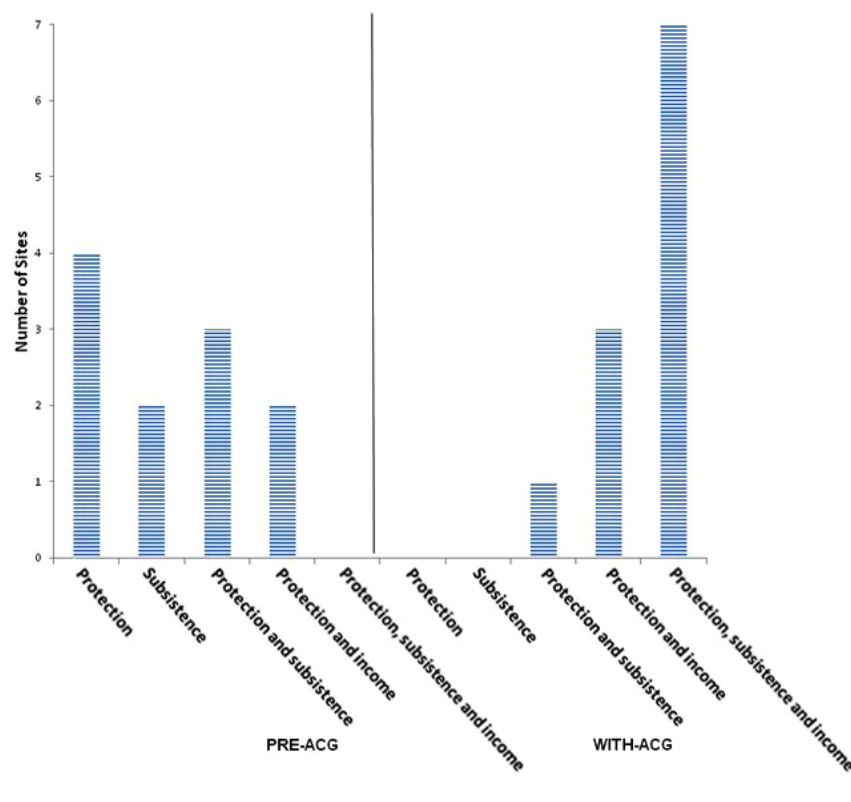

Prior to adaptive collaborative governance, the CFUGs did not offer reduced fees or subsidies to the poor nor recognize their 
Table 2. Changes in community forest user group (CFUG) rules and norms affecting distributional equity $(n=11)$. Notes: Changes between pre- and with-adaptive collaborative governance (2004-2007). CF = community forestry. Sources: CFUG executive committee and general assembly records, key informant interviews.

\begin{tabular}{ll}
\hline \hline CFUG policy areas & Rule changes [number of sites] \\
\hline Membership fees and levies & $\begin{array}{l}\text { Membership fee reduced for poor members [6], e.g., reduced by } 75 \%, 50 \% \text {, and 25\% for the poorest, poor, and } \\
\text { lower medium members, respectively. } \\
\text { Household levy reduced [3]. }\end{array}$ \\
Access to \& sale of CF products &
\end{tabular}

Timber fee reduced for the poor [5].

Poorest members (particularly single Dalit women) receive 5 cubic feet of timber free annually [1].

Poor members receive 10 cubic feet of timber free to construct toilet [1].

Free timber for fire and landslide victims [1].

$30 \%$ of timber allocated to the poor at a discount [1].

Poor members encouraged to begin cattle raising and are provided CF forest area for fodder production [1].

Differential rates for fuelwood for different wealth groups [2].

Poor users allowed to collect and sell fuelwood either legally [4] or informally [1].

Representation, opportunities, and health

Poor members can collect and sell nontimber forest products [1].

Policy to increase women's representation in CF decision-making bodies [5].

Quota for representation of Dalits and/or toles in CF decision-making bodies [2].

Women and poor members are prioritized for, or provided with, CF-related opportunities [5].

Subsidized rates for health insurance for poor CFUG members [1].

Priority to the poor in CF-related employment [2].

relative inability to pay when setting the level of membership or product fees. Table 2 indicates the substantial changes to rules and norms that were designed to increase accessibility and benefits for the poor.

The changes in fuelwood rules and norms were especially notable for Daure members (fuelwood sellers, mainly Dalit or more marginalized ethnic group members). Previously, these members had routinely broken CFUG rules to support their livelihoods, which had exposed them to risks of confiscation of tools, fines, and social retribution. Executive and other members regularly accused them of being "forest destroyers," scolded them in public, and drove them away from the general assemblies. As the changes in norms and rules began to gain traction, Daure members were no longer in a position of having to act illegally; this had the noticeable effect of reducing conflict at the sites. One Dalit woman stated "I am happy that I ... formally got permission from the executive committee to sell out the dry fuelwood for the option of my family livelihoods. Now I don't need to steal the fuelwood from the community forest ..." (female CFUG member).

The above changes in norms and rules were influenced by marginalized members beginning to have direct input into CFUG decision making (above). Women, the poor, and Dalit members progressively exercised this influence with greater knowledge and confidence than they previously had done because of the related increase in information flows (above). One Dalit member commented: "The local women's and marginalized users' representation has increased in tole committees, which has generated enthusiasm in us. The tole committees are making decisions in favor of women and the poor to provide CFUG funds and forest resources in an equitable manner. After this type of direct benefits, women's and the poor's participation has been increasing in CFUG activities including decision making" (female CFUG member).
The ongoing adjustment of rules was also influenced by the CFUGs being more proactive in information finding and generating, such as equity tracking, and joint reflection. For example, at one site members realized during one self-monitoring exercise that the existing pattern of forest product distribution was not equitable, especially regarding timber. As such they constituted a "forest product distribution monitoring committee," which was responsible for helping each tole assess the actual needs of their member households, so that could be used as the basis for distribution. In another example, at a different site a rule dictated that certain Dalit members (the Biswokarma) had to go to distant areas of the community forest to collect their fuelwood, while other members could collect from nearby areas. During the research period, Biswokarma members began to express their objections to this in executive meetings and assemblies; researchers observed that over time other members also started to express that this was socially biased and unjust. As a result, the rule was changed and Biswokarma members gained the same access rights as other members. This learning approach appeared to be supported by the increasing involvement with outside actors. As noted earlier, as well as bringing in outside information and insights, these actors sometimes offered discussion-provoking questioning of CFUG practices and their underlying assumptions and attitudes. Members were also increasingly exposed to the questioning of prior assumptions about equity and rights through interactions with or exposure to Maoists, through "educational speeches," dialogue, posters, radio, or to the broader civil discourse that emerged.

Finally, in terms of consequences, the changes in rules and norms and the underlying changes in governance contributed to members' sense of ownership, which in turn positively influenced the implementation of, and compliance with, forest management strategies and rules. Table 3 illustrates this with reference to one 
Table 3. Changes in working approach and ownership: thinning and pruning operation pre- and with-adaptive collaborative approach (2004 and 2007 compared). Source: Notebook record of local facilitator.

\begin{tabular}{lll}
\hline \hline $\begin{array}{l}\text { Aspects of operation } \\
\text { governance \& outcomes }\end{array}$ & Preadaptive collaborative approach & With adaptive collaborative approach \\
\hline Discussions & $\begin{array}{l}\text { Executive committee decided; asked toles to } \\
\text { participate in the operation } \\
\text { Executive committee members }\end{array}$ & $\begin{array}{l}\text { Discussed and decided in the meeting of tole leaders, who later } \\
\text { discussed in the respective toles } \\
\text { In addition to the executive committee members, paid members } \\
\text { and tole leaders also monitor } \\
\text { Making and following } \\
\begin{array}{l}\text { Secisions } \\
\text { Sense of ownership of } \\
\text { members }\end{array}\end{array}$ \\
\hline
\end{tabular}

CFUG's thinning and pruning operations. Compliance is significant both in terms of the degree to which forest management rules are followed, and in terms of a larger discussion of social capital and conflict because noncompliance can be a form of passive resistance. These positive trends in forest management and compliance across all sites are indicated in the CFUG's self-monitoring, as is the related CFUG perception of improvements in community forest condition (Appendix 2.2).

Effects: information sharing, distributional equity and inclusion, collaborative activities, and joint actions

The information sharing at the research sites changed with the routinization of active multilevel discussions and decisionmaking nodes (above), and the overall change in the CFUGs' emphases on more participatory, communicative, and accountable governance. This change is evidenced by the CFUGs' self-monitoring, in particular by the CFUGs' information-related indicators. The indicators, developed by each CFUG based on their own visions, included members' awareness of CFUG decisions and financial information, whether toles were directly informed of assembly and executive decisions, members' awareness of CFUG rights, roles, rules, and responsibilities, and whether members shared the knowledge and skills they gained from training sessions with other members. Of the total of 59 such information-related self-monitoring indicators developed and self-assessed by the respective CFUGs, 53 improved, 6 remained unchanged (all at short term sites), and none deteriorated over the research period.

Information sharing did not relate solely to "hard" information, such as about rules or technical forestry, but also to information regarding the needs, values, and perspectives of diverse subgroups. This included members' reflections on relative wellbeing and equity. Repetition of learning-oriented and inclusive information sharing practices, such as brainstorming about internal diversity and the positions of subgroups, wealth ranking and "equity-tracking", critical questioning of practices, appeared to contribute to building mutual understanding and to an increase in regard for others' perspectives. As one executive committee member remarked: "We never realized the say of women and the poor in the past, but adaptive collaborative management opened my eyes that every user knows something" (male executive committee member). During the field research, researchers and participants used the term "adaptive collaborative management"
(ACM) rather than "adaptive collaborative governance," this being the overall research program's terminology.

Members' perception of distributional equity is relevant here because this was a major and divisive issue that relates centrally to the degree of trust and cohesion in the CFUGs. The increased focus on equity, combined with the shifts in decision-making arrangements, processes, facilitation and leadership, networking, and the external (Maoist and civil) influences described above led to shifts in distribution of forest products over the course of the research (see McDougall et al. 2013a), and thus shifts in members perception of distributional equity. Pebble distribution exercises conducted at all sites at the conclusion of the research indicated that marginalized CFUG members perceived that benefit sharing had become more equitable with the transition to an adaptive collaborative approach (Fig. 3). The scores, however, all remain in the midrange, indicating scope for further improvement. Not all distribution issues are yet resolved to marginalized members' satisfaction. In 2 of the 11 CFUGs, for example, marginalized users expressed some remaining dissatisfaction with the degree of distributional equity regarding timber in their CFUGs at the end of the project period.

Figure 3 also sheds light on this issue from the perspective of the "distance" (difference) between perceptions of marginalized and nonmarginalized members. Figure 3 illustrates that the differences between the perceptions of marginalized and nonmarginalized members on this issue decreased with the transition to adaptive collaborative governance; in other words, their perceptions regarding a controversial issue became closer and more similar.

There were also documented increases in the CFUG members' sense of inclusion as they became more involved in decision making, received more respect from other members, and received more benefits. For example, Daure members at one site, who at the start of the project were treated by others as nonlegitimate rights holders, including being regularly scolded, became "proud members" to whom others proffered acknowledgement of their rights. Female members at another, began to increasingly voice their views and seek expanded roles in governance, and began to express a sense of ownership in the CFUG processes and decisions. A female tole representative from a different CFUG noted: "In the past our voice was not considered, but nowadays our sayings are counted and we are asked as well" (female CFUG member/tole representative). 
Fig. 3. Perception of distributional equity: comparing marginalized and nonmarginalized members in the pre- and with-adaptive collaborative governance periods $(n=11)$. Notes: Perception of distributional equity refers to perceptions of equity regarding access to key forest products (timber, nontimber forest products, fodder, fuelwood), community forest user groups (CFUG) loans and income generation activities, and trainings. Pre-ACG = prior to adaptive collaborative governance; with ACG = with adaptive collaborative governance, i.e., by study final assessments. Marginalized members $=$ poor, Dalit, and female members (all nonexecutive committee). Nonmarginalized members $=$ rich and medium wealth group, male, non-Dalit members, and executive committee members. A comparison of marginalized members perceptions from the pre-ACG and with ACG periods (the 1st and the 3 rd columns) indicates an increase in perception of equity among marginalized members. Comparison of both groups of members across these periods (the 1st and 2nd columns compared with the 3 rd and 4 th columns) illustrates a decrease in the gap between perceptions of marginalized and nonmarginalized members. Source: Pebble distribution exercises, 2006.

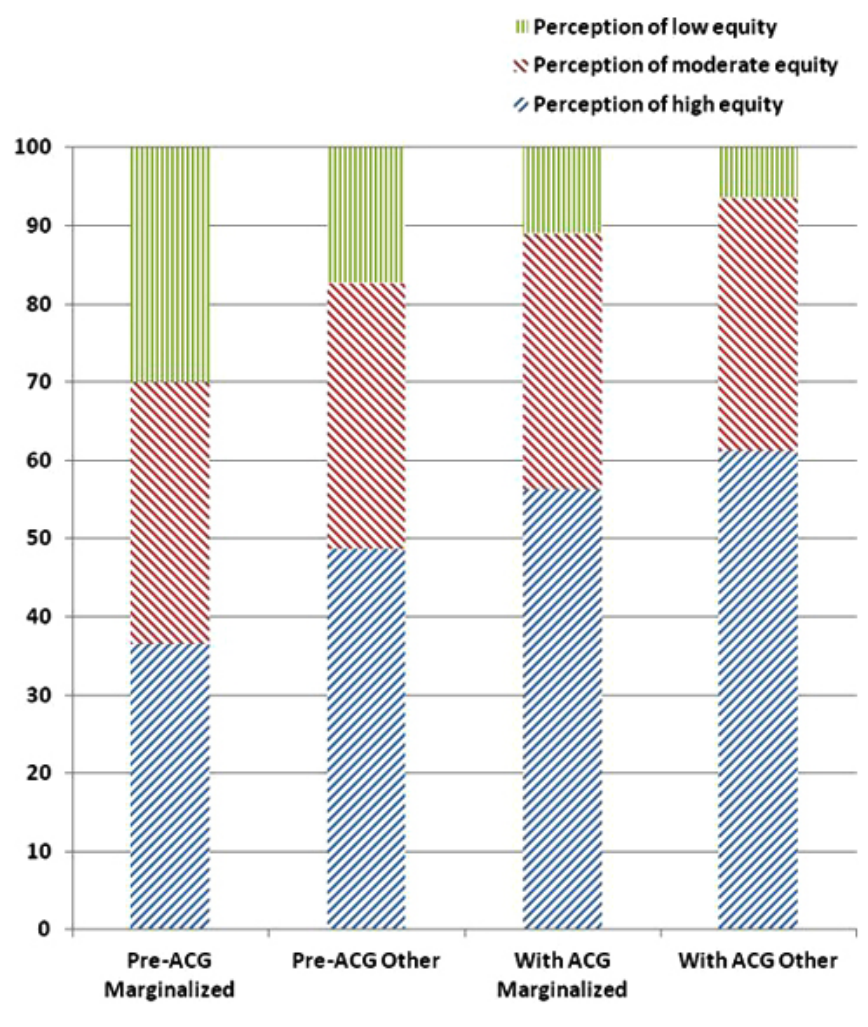

Explicit and inclusive visioning and routinized self-monitoring significantly expanded the number of action plans that the CFUGs created and implemented, compared with the preadaptive collaborative governance period (Fig. 4). Although some of the increased activities were relatively typical, such as thinning and pruning, fire protection, protecting trees from illegal harvest, others were surprisingly ambitious, such as membership
Fig. 4. Action plans and implementation: comparing pre- and with-adaptive collaborative governance $(n=11)$. Notes: $A C G=$ adaptive collaborative governance. Pre-ACG $=2000$ in the long-term sites $(n=4) ; 2004$ in the short-term sites $(n=7)$. With-ACG $=2006$ in all sites $(n=11)$. In the pre-ACG period, the most common action plans included some forest protection, plantation, or silvicultural activities and community development such as trail building. In three of the sites with no formal CFUG-agreed action plans in that period, the executive committees did undertake some forest protection or silviculture. In the with-ACG period, action plans expanded to additionally include more subsistence and income generation, such as animal-raising or nontimber forest products development, capacity building, and additional forest protection or conservation measures, including fireline construction. In this period, one site had 6 plans but 10 plans implemented because, in addition to its 6 plans, the CFUG implemented 4 additional, previously unimplemented, plans from the prior year. Sources: CFUG Annual Plans, executive committee and general assembly records, key informants, meeting and field observation.

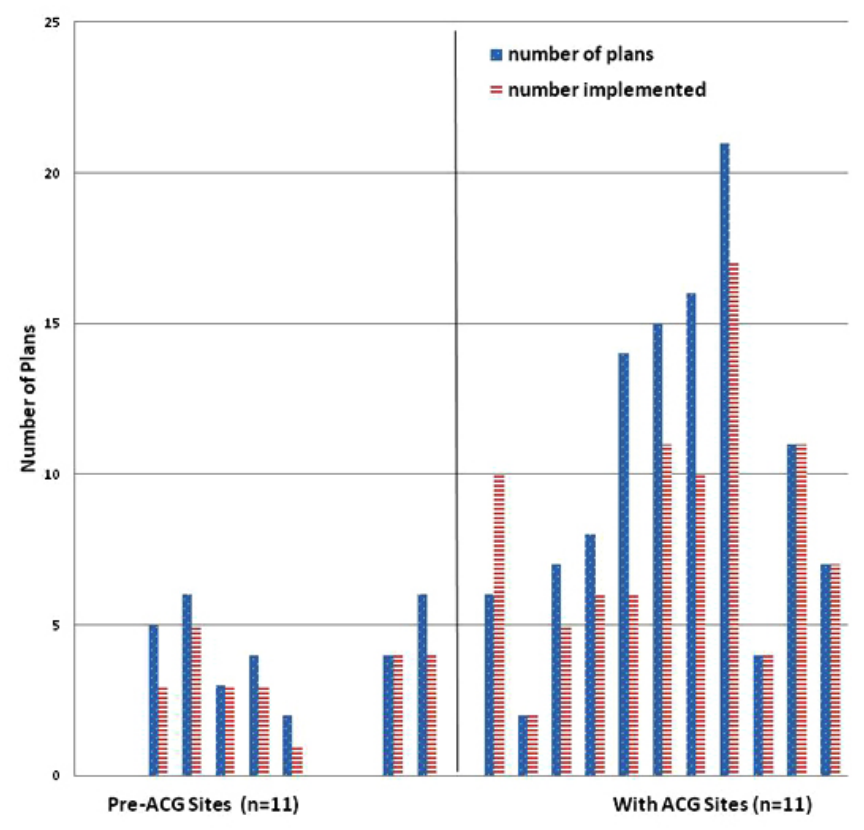

in a networked nontimber forest product enterprise, initiation of a Dalit-led sawmill, or formation of action groups such as a loan monitoring committee. The number of livelihood-oriented (income generation) activities increased from 6 to 31 activities across all sites, including animal raising and nontimber forest products. The number of such activities that were propoor and/ or prowomen oriented also increased, from 2 to 20 across all sites (see McDougall et al. 2013a). One Dalit woman from the poor wealth category stated, the adaptive collaborative governance process "has increased the representation of women in decisionmaking bodies, the participation is increasing for collective [activities], and access to resources is also increasing, that's why 
women are ready to continue the process in collaborating with men even in the future" (female CFUG member). Conversely, some plans, especially those related to income generation, were not successfully implemented if the external connections, leadership and/or follow-up were lacking or ineffective. Some activities were delayed or not implemented because of security problems.

There was an increase in joint actions as adaptive collaborative governance took hold, in particular in terms of marginalized members' claiming their rights. For example, members of a Dalit tole at one site identified their interests through tole reflection, organized and struggled for several years to be recognized, and ultimately successfully backed by their CFUG and outside actors in their hopes of starting a sawmill. At another site, a group of women led by a Dalit woman successfully organized to remove the chairperson of the CFUG because he had been using the CFUG cooperative funds for his own salary without authority. At a different site, during PAR women successfully organized to petition the executive committee to form a separate subcommittee to voice women's interests.

Additionally, during the research period there were instances of CFUG members engaging in joint actions vis-à-vis external actors, to an extent and in a way that appeared to be unprecedented in this context. Examples are presented in Appendix 2.3, including members at one site successfully rallying against the District Forest Officer to retain their CF rights, and at another site collectively deciding against outside commercialization of their community water.

\section{Evolution of CFUG Conflicts}

Increased engagement in decision making, related development of understanding between groups, and changes in norms and rules contributed to decreased conflict, for example, between Daure and other members/executive committees over firewood. The changes in power relations with which these were coupled reflected "pulls" or incentives to accommodate multiple interests, such as committee members valuing decreases in internal conflict and increases in respect of external actors, as well as "pushes," such as increasing demands of marginalized members and intangible pressure emanating from the presence of outside actors, both forest-related and Maoists.

However, the shift to adaptive collaborative governance also contributed to some existing conflicts flaring up and some hitherto latent or hidden tensions surfacing. Of the 12 conflicts identified at the outset (Table 4), 3 flared up in the early stages of the PAR, before eventually improving. Four additional tensions or conflicts surfaced during the PAR, which appeared to be latent issues brought to a boil as they were discussed more openly. At one site, for example, as poor users became more conscious of their rights and equity issues, especially through facilitated tolelevel discussions, they began to develop a greater stake in the CFUG. A delegation of poor users went to the executive committee to demand more community forest rights and benefits for poor users, which initially led to an open clash. The conflict dissipated, however, after CFUG leaders began to respond to the needs of the poor by, for example, organizing free CFUG membership and reduced prices for timber for the poor. In another example, at a different site the growing empowerment of female CFUG members led to some conflicts. For example, a subgroup of women asked to collaborate with the executive committee in leading the construction of a culvert in a road, an arrangement that was not taken comfortably by a male CFUG member who held power through their affiliation with a strong political party. This man angrily expressed, "it is because of sikaimukhi [adaptive collaborative approach] these women dared to challenge us." $\mathrm{He}$ resisted the women's involvement, but the women challenged him. This conflict was resolved through the engagement of the CFUG leadership and the leadership of other political parties. The women held their ground and successfully co-led the initiative.

Increased conflict, when combined with participatory and nested decision making and learning, gave rise to more proactive addressing of conflict and the use of varied conflict management mechanisms. The CFUGs began to rely on toles and other groups, rather than the executive committee or chairperson, to manage conflicts or potential conflicts. At one site, the CFUG was able to overcome a longstanding political rivalry that formerly overwhelmed their executive elections by basing the election in the toles. At another site, the chairperson observed: "When any conflicting issues arise in the CFUG, we do not play the role of the judge as we used to do previously, we send the issue to the concerned toles and the tole people themselves manage the case and come to the committee with their resolution, and the conflicting issues no longer remains in the CFUG" (male CFUG member). Special action groups were created at some sites to address conflict. For instance, conflict resolution committees that operated as needed to address illegal cutting and other issues were created at one site, and an encroachment monitoring committee was developed at another.

The improvement in conflict management is evidenced by the evolution of the main conflicts at each site. Of the 12 conflicts identified at the outset as pre-existing, 11 had improved significantly or been resolved by the end of the research, and the 1 remaining had not been directly addressed because the executive committee did not consider it to be CFUG related (Table 4). This improvement is also evidenced by the CFUGs' self-monitoring of intra-group relations, which showed increases over time (Appendix 2.4).

Three of the four "newly surfaced" latent conflicts improved during the PAR and at the remaining site the CFUG put a plan in place to address the remaining conflict (a disagreement about a resin collection plan). Some key points of contestation remained at some sites, however, in particular regarding timber, the most financially valuable of the forest resources.

Finally, some CFUGs began to extend their learning regarding conflict management to other spheres. For example, as outlined in Appendix 2.4, one tole extended their experiences down to the household level.

\section{DISCUSSION}

In broad terms, in line with Plummer et al. (2013), the evidence of this study underscores the relevance of adaptive collaborative approaches specifically to environmental governance. Moreover, in line with Anderson (2001), Jiggins and Röling (2002), Armitage et al. (2007), and others, it underscores the claim that adaptive collaborative approaches, although ripe with challenges, have contributions to make to NRM and development. The significance of the adaptive collaborative approach, and 
Table 4. Main intra-community forest user groups (CFUG) conflicts: issues, actors, timing, and evolution $(\mathrm{n}=11)$. Notes: PAR = participatory action research; $\mathrm{ACG}=$ Adaptive collaborative governance; $\mathrm{EC}=$ executive committee; $\mathrm{CF}=\operatorname{community}$ forest(ry); CFUG $=$ community forestry user group; $\uparrow=$ increased conflict; $(\uparrow)=$ slightly increased conflict; $\downarrow=$ decreased conflict; $(\downarrow)=\operatorname{slightly}$ decreased conflict. Sources: Focus group discussions, key informant interviews, observation.

\begin{tabular}{|c|c|c|c|c|}
\hline $\begin{array}{l}\text { Conflicts } \\
(\mathrm{n}=16)\end{array}$ & $\begin{array}{l}\text { Key issue(s) } \\
\text { (and actors) }\end{array}$ & $\begin{array}{l}\text { Emergence of } \\
\text { conflict }\end{array}$ & $\begin{array}{l}\text { Direction of } \\
\text { change } \\
\text { during PAR }\end{array}$ & Key changes in management of issue with ACG \\
\hline 1. & $\begin{array}{l}\text { Power conflict: domination of EC (poor } \\
\text { and women versus wealthy and male } \\
\text { members) }\end{array}$ & $\begin{array}{l}\text { Multiple years } \\
\text { pre-PAR }\end{array}$ & $\uparrow$ then $\downarrow$ & $\begin{array}{l}\text { Reflection processes on relations and equity; distribution of } \\
\text { leadership through tole committees; creation of EC positions for } \\
\text { Dalit and women. }\end{array}$ \\
\hline 2. & $\begin{array}{l}\text { Distributional equity: forest products } \\
\text { (especially poor versus elite/EC) }\end{array}$ & $\begin{array}{l}\text { Multiple years } \\
\text { pre-PAR }\end{array}$ & $\uparrow$ then $\downarrow$ & $\begin{array}{l}\text { Agreement that priority given to poor in distributing forest benefits } \\
\text { and opportunities; use of equity tracking tool. }\end{array}$ \\
\hline 3. & $\begin{array}{l}\text { CFUG membership, nonparticipation, and } \\
\text { domination } \\
\text { (members versus EC; Tamang, Magar, and } \\
\text { Rai indigenous groups versus Brahmin/ } \\
\text { Chhetri) }\end{array}$ & $\begin{array}{l}\text { Multiple years } \\
\text { pre-PAR }\end{array}$ & $\downarrow$ & $\begin{array}{l}\text { Involvement of members through tole discussions and collaborative } \\
\text { work; facilitated negotiation (and subsequent reinvolvement of } \\
\text { indigenous members in CF activities and leadership). }\end{array}$ \\
\hline 4. & $\begin{array}{l}\text { Boundary/CF land encroachment } \\
\text { (individual members versus EC) }\end{array}$ & $\begin{array}{l}\text { Multiple years } \\
\text { pre-PAR }\end{array}$ & $\downarrow$ & $\begin{array}{l}\text { Shift from EC control to active role of 'forestland encroachment } \\
\text { monitoring committee' and rotational forest patrolling system. }\end{array}$ \\
\hline 5. & $\begin{array}{l}\text { Inequitable distribution of timber } \\
\text { (medium and poor wealth class members } \\
\text { versus EC) }\end{array}$ & $\begin{array}{l}\text { Multiple years } \\
\text { pre-PAR }\end{array}$ & $\downarrow$ & $\begin{array}{l}\text { Shift from EC control to active role of "forest product distribution } \\
\text { committee" working with toles and committee. }\end{array}$ \\
\hline 6. & $\begin{array}{l}\text { Governance/power: nontransparent } \\
\text { accounting system (EC versus members) }\end{array}$ & $\begin{array}{l}\text { Multiyear pre- } \\
\text { PAR }\end{array}$ & $\downarrow$ & $\begin{array}{l}\text { Initial reflection processes sparked replacement of all EC members; } \\
\text { establishment of more transparent financial system. }\end{array}$ \\
\hline 7. & $\begin{array}{l}\text { Selling of fuelwood } \\
\text { (fuelwood sellers versus nonfuelwood } \\
\text { sellers and EC) }\end{array}$ & $\begin{array}{l}\text { Multiyear pre- } \\
\text { PAR (intense } \\
\text { since CFUG } \\
\text { inception) }\end{array}$ & 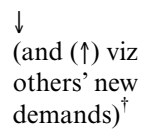 & $\begin{array}{l}\text { Adjustment in processes that led to changes in rules and livelihood } \\
\text { options: tole level discussions, reflections about equity, discussions } \\
\text { with meso actors, "legalization" of fuelwood sale for poor. }\end{array}$ \\
\hline 8. & $\begin{array}{l}\text { Power and governance: corruption/misuse } \\
\text { of power and illegal cutting and sale of } \\
\text { timber by EC (EC versus members) }\end{array}$ & $\begin{array}{l}\text { Pre-PAR: Severe } \\
\text { for four years } \\
\text { prior }\end{array}$ & $\begin{array}{l}\downarrow \\
\text { (with new } \\
\text { EC) }\end{array}$ & $\begin{array}{l}\text { Change in EC selection process to tole-based one; increasing } \\
\text { member-EC and CFUG-meso forum communication; strengthened } \\
\text { accountability and transparency; (stopped illegal harvest and sale). }\end{array}$ \\
\hline 9. & $\begin{array}{l}\text { Governance: distrust/noncooperation } \\
\text { (EC versus members, wealthy versus poor) }\end{array}$ & $\begin{array}{l}\text { Multiple years } \\
\text { pre-PAR }\end{array}$ & $\downarrow$ & $\begin{array}{l}\text { Development of common vision, decentralization of EC roles to } \\
\text { thematic groups and toles, tole-EC communication mechanisms } \\
\text { established, began EC documentation processes. }\end{array}$ \\
\hline 10. & $\begin{array}{l}\text { Settlements and resource distribution } \\
\text { between toles } \\
\text { (Rai versus Newar leaders and toles) }\end{array}$ & $\begin{array}{l}\text { Multiple years } \\
\text { pre-PAR }\end{array}$ & --- & $\begin{array}{l}\text { Not directly addressed: EC considered it an inter-tole conflict, not } \\
\text { directly CF-related. However, indirectly addressed by making the } \\
\text { EC leadership more inclusive of the less powerful Rai group. }\end{array}$ \\
\hline 11. & $\begin{array}{l}\text { General nonCF conflicts } \\
\text { (among members, e.g., women's group }\end{array}$ & $\begin{array}{l}\text { Multiple years } \\
\text { pre-PAR }\end{array}$ & $\uparrow$ then $\downarrow$ & $\begin{array}{l}\mathrm{EC} \text { and tole committees are now regularly called on to support } \\
\text { management of nonCF conflicts. }\end{array}$ \\
\hline
\end{tabular}

12. Power conflict: domination of key EC roles and influence

(periodic)

Pre-PAR since $\quad \downarrow$

CFUG

(male versus female, EC versus members) formation

13. Rivalry/clash of political ideology in local 'Hidden' (became

leaders

clear during

(between followers of different political PAR)

14. Distributional equity (marginalized members versus EC)

"Hidden"; flared $\uparrow$ then $\downarrow$ following tole discussions in background studies Unclear start; $\quad(\downarrow)^{\ddagger}$ surfaced during . PAR

Toward the end of PAR
Established rule regarding reserved EC seats and portfolios and tole committee seats for women.

Change in leadership selection process: Use of toles to select EC in less partisan manner; tole level meetings, and planning and selfmonitoring enabling more interaction and communication.

Development of propoor activities; increased interface and negotiation between members and EC.

Meso forum and EC negotiated resolution with alleged "encroacher" who was from a poor household. Individual was given tole committee role and 4 year use and management rights to a plantation area.

Conflict resolution plan prepared; proactive management of conflict by committee.

(EC/tole committees versus a few members)

${ }^{\dagger}$ Improvement of this fuelwood issue, but the addressing of this issue sparked vocalization of discontent from members with other interests who would like similar support from the EC for their issues. These were starting to be raised through tole and other processes.

${ }^{\ddagger}$ The one case that was raised formally was resolved; other alleged cases not yet formally raised. 
concomitant changes in social capital and conflict, to both NRM and development-related goals were evident in several ways in this study. The emergent changes were tied to an increase in collaborative activities supporting community development through livelihood opportunities, especially for the poor. These increases were linked to a shift away from the conservationistorientation traditionally associated with the patron-client paradigm, which Malla (2001) argues is one of the most important limiting factors to the achievement of propoor outcomes. The changes were also tied to an expansion of joint actions relating to community rights and good governance. At the same time, these changes were linked to greater collaborative activities in forest protection and management, which imply a potential strengthening of environmental sustainability.

Turning more specifically to this study's main lines of inquiry, the evidence indicates that although not all issues were resolved, nor universal satisfaction achieved, positive changes in social capital and reductions in conflict did occur during the research period and that these trends can be plausibly attributed to adaptive collaborative governance. Equally compelling as these findings, are the "surprises" that emerge in terms of the dialectical patterns and dynamics among conflict, social capital, and adaptive collaborative governance. It is these we now discuss. To explore the dialectic in more depth, we explore the interplay between the following: adaptive collaborative governance and conflict; adaptive collaborative governance and social capital; and conflict and social capital.

\section{Adaptive collaborative governance and conflict}

Although the sites were considered typical in terms of internal relations at the time of site selection, conflict was pervasive within the CFUGs. This signals the first of two interesting points that emerged in terms of conflict. First it emphasizes that collaborative resource management, even within well-established programs such as Nepal's, is inherently potentially prone to conflict. This is not to suggest that such conflict is intractable, but rather that some conflict, including latent and hidden tensions, is an inevitable part of NRM. Similarly, "power-with its many faces -is a fundamental issue in natural resource management" (Ballet et al. 2007:364). This is true as well in community development more broadly, as indicated by Chambers (2004) and his underscoring the need to recognize power and relationships in that context. Our study reinforces this, indicating that explicit recognition of conflict and power in natural resource governance policy, practice, and institutional support, and by extension, in these facets of development, would allow these issues to be better addressed (Vo $\beta$ and Bornemann 2011).

The second point of interest is the largely unanticipated effect of efforts to collaborate bringing latent tensions to the surface and sparking simmering tensions into more open conflict. This underscores that social and institutional, and thus power-related, change is not smooth but rather is full of twists and challenges. This is not, however, simply a case of "two steps forward, one step back." We perceive the surfacing of conflict in these cases as having also been a useful part of conflict management in that it brought the underlying power-related issues to light. Once surfaced, they could be acknowledged and addressed within the context of the shared reflection and reform of power and governance. From this perspective, the surfacing of the conflicts, within this constructive context, was an integral part of the CFUGs' ultimately becoming better equipped to address conflict over time.

This has implications for the framing of collaboration and conflict in governance. Instead of an assumption of neutral relations as the starting point for collaboration, and the premise of seeking to "work together" in an undifferentiated power field, collaboration might usefully be framed as the nuanced convergence of measures to redress power imbalances, to manage or heal conflict, and to identify the need and ways for working together. As Funder (2012:1725) suggests, "this may include taking a more politically explicit and polycentric approach, in which conflict of interests within and beyond communities are treated not as a problem, but as a necessary and dynamic aspect of the political process." In the case of adaptive collaborativerelated approaches, this would be intertwined with equityoriented social learning and action.

\section{Adaptive collaborative governance and social capital}

This study indicated that, despite the sites being considered typical in their relations, the nature and level of social capital in the CFUGs was far less than optimal prior to adaptive collaborative governance. The internal groups' information sharing and external networking were limited, rules reflected a noninclusive environment, and trust and social cohesion were low within CFUGs. In the terms of Pretty (2003), this reflects low bonding, bridging, and linking social capital.

Moreover, the study indicates subtleties and nuances that are not much explored in the literature. Taking Leach et al.'s (1999) emphasis on diversity within communities, we suggest that there were multiple and overlapping spheres of social capital that differed and needed to be addressed. Although it was significant that the social capital of each site as a whole was low at the outset of the research, it was equally significant that the social capital of the elite members as a group (wealthier, male, high caste) was high relative to that of the marginalized members as a group (women, the poor, Dalit). Elite members together dominated the available groups (the executive committees) and networks (the scant relations with outside actors), and thus controlled information, and shaped the rules and norms. By their own expressed views, and from an external perspective, the elite, represented by the chairperson and executive members, "were" the CFUG. This is in line with the FAO's (2006:17) noting that community forestry could be equally referred to as "committee forestry." The CFUGs' conservation-orientation was reflective of the alliance between the techno-bureaucracy and CFUG elite (Malla 2001, Nightingale 2005, Ojha 2006). This phenomenon of domination is not limited to community forestry, but poses a risk in community development more broadly (Fritzen 2007). Ballet et al. (2007) warn of the risk that if development interventions do not address these power-related patterns, then attempts to strengthen ties between communities and external agents may contribute to the perpetuation or even the increase of inequalities within communities by reinforcing the elite's advantages (Ballet et al. 2007). We concur and note that external or internal efforts to increase community social capital could inadvertently reinforce existing domination and marginalization, if such efforts mistake the dominant group for the more complex whole. 
In contrast, marginalized members had relatively low social capital as a group and in relation to the CFUG as a whole prior to adaptive collaborative governance. In particular, they had little engagement in the CFUG's groups or networks, they had little influence over the rules to which they were formally bound, in some cases they consistently broke the rules, and there was low observable cohesion among marginalized members (e.g., no observed joint actions) as well as low cohesion with the rest of the CFUG (expression of low sense of ownership and perception of being under-valued). Overall, this can be seen as an example of the effects of the "dark side" of social capital (Ostrom 1999, Ballet et al. 2007; R. Bolton, unpublished manuscript): the elite members' relatively high social capital, reinforced by their domination of and identification with the CFUGs, contributed to ongoing exclusion of marginalized members.

The findings indicate that adaptive collaborative governance positively influenced social capital over time, although there were remaining issues and room for improvement. The CFUGs increased their internal groups and external networks, worked more inclusively to develop rules and enhance compliance, and became more cohesive and better at managing conflict. The rapprochement of perceptions of equity illustrates a lessening of the cognitive divides (see Röling 2002) between the elite and nonelite members.

The change in social capital in the CFUGs was not a uniform, lineal increase in overall CFUG social capital. Rather, it can be, albeit simplistically, interpreted as a two-fold change: a reshaping of the social capital of the elite and the CFUG as a whole, away from overidentification of the elite as "the CFUG"; and a building of the marginalized members' own social capital. The shift to adaptive collaborative governance, and the surfacing of conflict, appeared to contribute to breaking down the resilience of the previous negative aspects of elite social capital. The transition toward a livelihoods-orientation illustrates, for example, both increasing inclusiveness and also the stimulation of innovation, i.e., movement away from the traditionally held conservation orientation of elite-technobureaucratic interests and development of new and alternatively-oriented initiatives. Meanwhile, marginalized members' social capital expanded in terms of their involvement in groups and networks (with each other, the CFUG, and outside actors), their involvement in shaping rules, and their sense of ownership and cohesion with the CFUGs. Linking to community development, these findings echo Krishna's (2007) study that found "involvement in self-initiated organizations" (in our study, tole meetings and action groups) and "agreement with rules" as key contributors to social capital. As Plummer and FitzGibbon (2007) highlight, it appears that there are potentially mutually enforcing feedback loops between social capital and collaboration, rather than a one-way influence. Social learning may play a key role in this: as Pretty and Ward (2001:214) note, "advances in social capital creation have been centred on participatory and deliberative learning processes."

\section{Conflict and social capital}

We have flagged two surprises that emerged in the sites that indicate the inter-related nature of conflict and social capital. First, some surfacing of conflict within the local level was an unanticipated outcome of efforts toward better internal collaboration. Second, is that the surfacing of conflict, in the context of facilitated social learning with an equity focus, was ultimately constructive in terms of social capital in that it contributed to the more effective and equitable addressing of long standing issues and power imbalances. Additionally, the study indicates that the successful navigating of conflicts, in terms of marginalized members or by CFUGs as a whole challenging perceived inequities, may have contributed to strengthening social confidence and cohesion and making constructive change. This corresponds to Fabricius et al.'s (2007) observation that, if appropriately managed, conflict may contribute positively to communities' capacity to respond to external threats.

More broadly, the national level conflict indubitably caused tremendous human suffering, loss, and hardship. Some of its widespread effects, including challenges to building trust, ability to travel, and gather safely, and loss of meso-level operations, were directly contrary to the needs and aims of adaptive collaborative governance. At the same time, the study indicated that as well as these considerable negatives, a couple of aspects of the conflict, embedded within a context of a broader civil movement and discourse, ultimately appeared to have had a surprising constructive influence on adaptive collaborative governance and social capital. For example, we concur with Pokharel and Paudel (2005) that the conflict may have acted as a motivating factor in local power shifts, contributing to a reluctance among dominant members to risk being perceived by Maoists as abusive of power. More broadly, the widespread discourse about rights, equity, and governance that was central to the civil movement and the Maoist conflict permeated rural areas, including Dalit and poor Nepalis. Although this specific link cannot be concretely established, we suggest that the discourse aspects of the movement and the conflict contributed to increasing marginalized CFUG members', and others', awareness of Dalit and other marginalized peoples' rights and value as citizens (symbolic capital) and equity issues in general. It may thus potentially have strengthened these members' willingness to work together to challenge authority (social capital), as well as potentially engendered more rapid and possibly more significant responses of CFUG leaders to demands from marginalized members.

We suggest that this influence reflects not only the conflict's and broader civil movement's discourse heralding in a certain prodemocracy, anticorruption zeitgeist, but more fundamentally reflects its contributing to a window of opportunity for marginalized members, and others, to perceive and challenge previously uncontested "doxa." Drawing on Bourdieu (1991), doxa refers to society's "unquestionable orthodoxy that operates as if it were the objective truth" (Chopra 2003:419). In other words, it is social agents' sets of "deeply held assumptions and values" (Cameron and Ojha 2007:69). Tacit acceptance of these unquestioned "truths" entrench stability of social order (Bourdieu 1991, Cameron and Ojha 2007). In the case of Nepal, and the CFUGs themselves, the doxa being brought to light was the previously unquestioned socio-political hierarchy, exclusions, and de facto limits on rights.

In this sense there was a certain unexpected synergy between the equity focus of the civil movement and national conflict and that of the adaptive collaborative governance. Assumptions regarding social equity being drawn into public scrutiny and discourse at 
multiple levels and spheres, in parallel with the increased deliberative focus of the adaptive collaborative governance within the CFUG, plausibly contributed subtly to eroding the resilience of previously inequitable patterns in CFUGs, including exclusionary effects of dominant groups' (internal) social capital. Although this was eroding, these same forces were transforming (increasing) the social capital between dominant and nondominant groups. Although the conflict's human impact was tragic and its long-term national influence still unknown, the emergent associated proequity discourse of the conflict and movement may have played an unexpected role in the sites in contributing to social cohesion among marginalized $\mathrm{CFUG}$ members, while also creating space for innovation in the form of more collaborative (and equitable) CFUG governance.

\section{CONCLUSION}

Social capital, rather than being "low" or "high" in the sites, was better understood as overlapping combinations: relatively low within the marginalized groups and in each CFUG as a whole, but relatively high among each CFUG's elite members. Adaptive collaborative governance changed, rather than uniformly built, social capital. Although the social capital of the marginalized members grew, the exclusionary effect and lack of innovation in orientation associated with the dominant members' own (internal) social capital eroded. At the same time, the CFUGs' overall (whole group) social capital developed in a manner that reflected an expanded sense of identity: more diverse and with an orientation that accommodated marginalized members' needs.

One contrasting element that emerged in the study was that despite the sites being part of a well-established participatory community-based NRM program that acknowledges equity as a priority, conflict was found to be pervasive, including regarding equity. Interestingly, although efforts to increase collaboration through adaptive collaborative governance necessitated more active conflict management and led to more effectiveness in that sphere, it also led to the surfacing of some conflicts. In fact, the path to more equitable and effective internal collaboration and the changes in social capital was arguably based on the underlying power relations and tensions, and conflict, being brought to the surface and addressed. A surprising connection to the macrocontext emerged in relation to conflict: although adaptive collaborative governance was elucidating the need for equity and inclusion within CFUGs, the national-scale conflict and civil movement were reinforcing this, through different means, more broadly. All were bringing previously unquestioned doxa regarding hierarchies and exclusions into public discourse.

Thus the sites reveal a messy and dynamic reality, woven through feedback loops: multifarious and overlapping subsets of dynamic social capital including perverse aspects; efforts toward collaboration contributing to conflict; and the constructive aspects of the conflicts at different scales ultimately contributing in some ways toward the changes in power and social capital needed for collaboration. As such, the study generates several insights for policy and practice. First, the study generates a caveat: policies or initiatives that do not make effective efforts to assess the complexities of social capital within communities and CBNRM groups, could easily confuse building the social capital of the dominant actors for building the social capital of the whole communities or groups, thus unintentionally reinforcing perverse effects. Second, with sufficient time and commitment, social learning-based approaches to NRM, such as adaptive collaborative governance, have the potential to make a contribution to conflict management and improved relations, as well as contribute to positive shifts in social capital. Moreover, based on the changes in actively implemented plans and external connections, these approaches can plausibly contribute to more proactive and successful CBNRM groups, and more broadly, to sustainable development.

The relationships and forces among these, however, are neither lineal nor straightforward. Conflict in NRM, governance, and development, even within local groups, needs to be acknowledged as part of the social-ecological landscape, and NRM group formation and institutional support needs to recognize and address this. Actors in policy and practice need to be cognizant of the nuances of groups and communities, including power relations within and between NRM groups and other external actors, to support the development of social capital that supports sustainable, including equitable, development. Collaboration, within communities or between them and external actors, could be usefully framed as multifaceted, embodying the convergence of addressing power imbalances, healing conflict, and working together, possibly linked through social learning and action. The fact that shifts in metadiscourse appeared to influence local level CFUG governance, implies the need for conscious scrutiny of assumptions in NRM and development at all scales.

More broadly, the intertwined and living landscape of NRM, governance, and development needs to be understood as messy and full of surprises. As well as implying the need for sufficient human capacities within local groups and supporting agencies, this underscores the need for a perspective on NRM, governance, and development that is adaptive and collaborative in nature. In other words, it reinforces the call for an equity-oriented, inclusive, nuanced, flexible, and social learning-based perspective to help actors at all scales effectively navigate the murky and unexpected in NRM, governance, and the pursuit of sustainable development. ${ }^{[1]}$ Dalit is a generic term used for the so-called "lowest" caste category within the Hindu caste system, a category that was historically also termed the "untouchables." In Nepal, Dalits are the most marginalized groups in terms of access to public decision-making structures, resources, and incidence of socio-cultural discrimination.

Responses to this article can be read online at: http://www.ecologyandsociety.org/issues/responses. $\mathrm{php} / 7071$

\section{Acknowledgments:}

This research was part of the international Adaptive Collaborative Management ( $A C M)$ Project led by the Center for International Forestry Research (CIFOR). The authors sincerely acknowledge CIFOR for permission to use the data, as well as research partners ForestAction Nepal, New ERA, and ERI and independent consultants. We also gratefully acknowledge the essential roles played by all those involved in the research: the CFUGs and their facilitators; all researchers and assistants; national and 
international advisors; collaborators from the Ministry of Forests and Soil Conservation and its Community Forestry Division, and the staff of the many district forest offices, bilateral projects, NGOs, FECOFUN, and meso forums and networks involved. We sincerely acknowledge the main funding agencies, namely the Asian Development Bank and Canada's International Research Development Centre (IDRC). We similarly acknowledge the complementary funding provided by the CG Systemwide Programme on Participatory Research and Gender Analysis, the International Institute for Rural Reconstruction (IIRR), and LIBIRD Nepal. Sincere thanks go to Janice Jiggins and Cees Leeuwis and to the anonymous reviewers and journal editors for their extremely valuable feedback on the article. We sincerely thank the Knowledge, Technology, and Innovation Group (KTI), Department of Social Sciences, Wageningen University for generously providing funding for open access publication.

\section{LITERATURE CITED}

Adler, P. S., and S. Kwon. 2002. Social capital: prospects for a new concept. Academy of Management Review 27(1):17-40. http://dx. doi.org/10.2307/4134367

Anderson, J. 2001. On the edge of chaos: crafting adaptive collaborative management for biological diversity conservation in a pluralistic world. Pages 171-185 in L. Buck, C. Geisler, J. Schelhas and E. Wollenberg, editors. Biological diversity: balancing interests through adaptive collaborative management. CRC, Boca Raton, Louisiana, USA. http://dx.doi. org/10.1201/9781420042597.ch9

Argyris, C., and D. Schön. 1996. Organizational learning II: theory, method and practice. Addison-Westley, Reading, UK.

Armitage, D., F. Berkes, and N. Doubleday, editors. 2007. Adaptive co-management: collaboration, learning, and multi-level governance. UBC Press, Vancouver, British Columbia, Canada.

Ballet, J., N. Sirven, and M. Requiers-Desjardins. 2007. Social capital and natural resource management: a critical perspective. Journal of Environment and Development 16(4):355-374. http://dx. doi.org/10.1177/1070496507310740

Barndt, D. 1989. Naming the moment: political analysis for action. Jesuit Centre for Social Faith and Justice, Toronto, Ontario, Canada.

Berkes, F., J. Colding, and C. Folke. 2003. Navigating socialecological systems: building resilience for complexity and change. Cambridge University Press, Cambridge, UK. http://dx.doi. org/10.1017/CBO9780511541957

Bodin, Ö., and B. I. Crona. 2008. Management of natural resources at the community level: exploring the role of social capital and leadership in a rural fishing community. World Development 36(12):2763-2779. http://dx.doi.org/10.1016/j. worlddev.2007.12.002

Bourdieu, P. 1991. Language and symbolic power. Polity, Cambridge, Massachusetts, USA.

Cameron, J., and H. Ojha. 2007. A deliberative ethic for development: a Nepalese journey from Bourdieu through Kant to Dewey and Habermas. International Journal of Social Economics 34:66-87. http://dx.doi.org/10.1108/03068290710723372
Central Bureau of Statistics (CBS). 2002. Population census 2001: national report. Central Bureau of Statistics, Government of Nepal, Kathmandu, Nepal.

Central Bureau of Statistics (CBS). 2012. National population and housing census 2011. Central Bureau of Statistics, Government of Nepal, Kathmandu, Nepal.

Chambers, R. 1983. Rural development: putting the last first. Longman, New York, New York, USA.

Chambers, R. 2004. Ideas for development: reflecting forwards. IDS Working Paper 238. Institute of Development Studies, Brighton, UK.

Chopra, R. 2003. Neoliberalism as doxa: Bourdieu's theory of the state and the contemporary Indian discourse on globalization and liberalization. Cultural Studies 17(3-4):419-444. http://dx.doi. org/10.1080/0950238032000083881

Coleman, J. S. 1988. Social capital in the creation of human capital. American Journal of Sociology 94:S95-S120. http://dx. doi.org/10.1086/228943

Colfer, C. J. P. 2005. The complex forest: communities, uncertainty, and adaptive collaborative management. RFF, Washington, D.C., USA.

Colfer, C. J. P., M. A. Brocklesby, C. Diaw, P. Etuge, M. Günter, E. Harwell, C. McDougall, N. M. Porro, R. Porro, R. Pranhu, et al. 1999a. The BAG: basic assessment guide for human well-being. Criteria \& Indicators Toolbox Series No. 5. Center for International Forestry Research, Bogor, Indonesia.

Colfer, C. J. P., M. A. Brocklesby, C. Diaw, P. Etuge, E. Harwell, C. McDougall, N. M. Porro, R. Porro, R. Pranhu, et al. $1999 b$. The grab bag: supplementary methods for assessing human wellbeing. Criteria \& Indicators Toolbox Series No. 6. Center for International Forestry Research, Bogor, Indonesia.

Cox, M., G. Arnold, and S. Villamayor Tomás. 2010. A review of design principles for community-based natural resource management. Ecology and Society 15(4): 38. [online] URL: $\underline{\text { http:// }}$ www. ecologyandsociety.org/vol15/iss4/art38/

Department of Forests. [date unknown]. Community forestry. Department of Forests, Ministry of Forests and Soil Conservation, Government of Nepal. [online] URL: http://dof. gov.np/dof_community_forest_division/community forestry dof

Fabricius, C., C. Folke, G. Cundill, and L. Schultz. 2007. Powerless spectators, coping actors, and adaptive co-managers: a synthesis of the role of communities in ecosystem management. Ecology and Society 12(1): 29. [online] URL: http://www.ecologyandsociety. org/vol12/iss1/art29/

Fals-Borda, O., and M. A. Rahman. 1991. Action and knowledge: breaking the monopoly with participatory action research. Intermediate Technology Publications, Apex Press, London, UK.

Fisher, R., R. Prabhu, and C. McDougall. 2007. Introduction: people, forests and the need for adaptation. Pages 1-15 in R. Fisher, R. Prabhu, and C. McDougall, editors. Adaptive collaborative management of community forests in Asia: experiences from Nepal, Indonesia and the Philippines. Center for International Forestry Research, Bogor, Indonesia. 
Food and Agriculture Organization (FAO). 2006. Understanding forest tenure in South and Southeast Asia. Forestry Policy and Institutions Working Paper No. 14. FAO, Rome, Italy.

Fritzen, S. A. 2007. Can the design of community-driven development reduce the risk of elite capture? Evidence from Indonesia. World Development 35(8):1359-1375. http://dx.doi. org/10.1016/j.worlddev.2007.05.001

Funder, M. 2012. The social shaping of participatory spaces: evidence from community development in Southern Thailand. Journal of Development Studies 46:1708-1728. http://dx.doi. org/10.1080/00220388.2010.492858

Glasl, F. 1999. Confronting conflict: a first-aid kit for handling conflict. Howthorn, Gloucestershire, UK.

Godfray, H. C. J., J. R. Beddington, I. R. Crute, L. Haddad, D. Lawrence, J. F. Muir, J. Pretty, S. Robinson, S. M. Thomas, and C. Toulmin. 2010. Food security: the challenge of feeding 9 Billion. Science 327(5967):812-818. http://dx.doi.org/10.1126/ science. 1185383

Gruber, J. S. 2010. Key principles of community-based natural resource management: a synthesis and interpretation of identified effective approaches for managing the commons. Environmental Management 45(1 ):52-66. http://dx.doi.org/10.1007/s00267-008-9235y

Jiggins, J., and N. Röling. 2002. Adaptive management: potential and limitations for ecological governance of forests in a context of normative pluraformity. Pages 93-104 in J. A. E. Oglethorpe, editor. Adaptive management: from theory to practice. International Union for Conservation of Nature, Gland, Switzerland.

Kanel, K. R., and G. R. Dahal. 2008. Community forestry policy and its economic implications: an experience from Nepal. International Journal of Social Forestry 1(1):50-60.

Kellert, S. R., J. N. Mehta, S. A. Ebbin, and L. L. Lichtenfeld. 2000. Community natural resource management: promise, rhetoric, and reality. Society \& Natural Resources 13(8):705-715. http://dx.doi.org/10.1080/089419200750035575

Krishna, A. 2007. How does social capital grow? A seven-year study of villages in India. Journal of Politics 69(4):941-956. http:// dx.doi.org/10.1111/j.1468-2508.2007.00600.x

Leach, M., R. Mearns, and I. Scoones. 1999. Environmental entitlements: dynamics and institutions in community-based natural resource management. World Development 27(2):225-247. http://dx.doi.org/10.1016/S0305-750X(98)00141-7

Lee, K. N. 1993. Compass and gyroscope: integrating science and politics for the environment. Island, Washington, D.C., USA.

Leeuwis, C., and R. Pyburn, editors. 2002. Wheelbarrows full of frogs: social learning in rural resource management. Koninklijke Van Gorcum, Assen, The Netherlands.

Lilja, N., and J. Ashby. 2000. Types of participatory research based on locus of decisionmaking. PRGA Working Document 6. CGIAR Systemwide Programme on Participatory Research and Gender Analysis, Cali, Columbia.
Lyon, F. 2000. Trust, networks and norms: the creation of social capital in agricultural economies in Ghana. World Development 28(4):663-681. http://dx.doi.org/10.1016/S0305-750X(99)00146-1

Malla, Y. B. 2001. Changing policies and the persistence of patron-client relations in Nepal: stakeholders' responses to changes in forest policies. Environmental History 6(2):287-307. http://dx.doi.org/10.2307/3985088

McDougall, C., J. Jiggins, B. H. Pandit, S. K. Thapa Magar Rana, and C. Leeuwis. 2013a. Does adaptive collaborative forest governance affect poverty? Participatory action research in Nepal's community forests. Society \& Natural Resources 26 (11):1235-1251. http://dx.doi.org/10.1080/08941920.2013.779344

McDougall, C., H. Ojha, M. R. Banjade, B. H. Pandit, T. Bhattarai, M. Maharjan, and S. Rana. 2008. Forests of learning: experiences from research on an adaptive collaborative approach to community forestry in Nepal. Center for International Forestry Research, Bogor, Indonesia.

McDougall, C. L., C. Leeuwis, T. Bhattarai, M. R. Maharjan, and J. Jiggins. 2013b. Engaging women and the poor: adaptive collaborative governance of community forests in Nepal. Agriculture and Human Values 30(4):569-585. http://dx.doi. org/10.1007/s10460-013-9434-X

Mezirow, J. 1997. Transformative learning: theory to practice. New Directions for Adult and Continuing Education 74:5-12. http:// dx.doi.org/10.1002/ace.7401

Nath, T. K., M. Inoue, and J. Pretty. 2010. Formation and function of social capital for forest resource management and the improved livelihoods of indigenous people in Bangladesh. Journal of Rural and Community Development 5(3):104-122.

Nightingale, A. J. 2005. "The experts taught us all we know": professionalisation and knowledge in Nepalese community forestry. Antipode 37(3):581-604. http://dx.doi.org/10.1111/ j.0066-4812.2005.00512.x

Ojha, H. R. 2006. Techno-bureaucratic doxa and the challenges of deliberative governance: the case of community forestry policy and practice in Nepal. Policy and Society 25(2):131-175. http:// dx.doi.org/10.1016/S1449-4035(06)70077-7

Ojha, H. R., A. Hall, and R. Sulaiman V. 2013. Adaptive collaborative approaches in natural resource governance. Earthscan, Oxon, UK.

Olsson, P., C. Folke, and F. Berkes. 2004. Adaptive comanagement for building social-ecological resilience. Environmental Management 34(1):75-90. http://dx.doi.org/10.1007/s00267-003-0101-7

Olsson, P., L. H. Gunderson, S. R. Carpenter, P. Ryan, L. Lebel, C. Folke, and C. S. Holling. 2006. Shooting the rapids: navigating transitions to adaptive governance of social-ecological systems. Ecology and Society 11(1): 18. [online] URL: http://www. ecologyandsociety.org/vol11/iss1/art18/

Ostrom, E. 1990. Governing the commons: the evolution of institutions for collective action. Cambridge University Press, Cambridge, UK. http://dx.doi.org/10.1017/CBO9780511807763 
Ostrom, E. 1999. Social capital: a fad or fundamental concept? Pages 172-214 in P. Dasgupta and I. Sergeldin, editors. Social capital: a multi-faceted perspective. The World Bank, Washington, D.C., USA.

Ostrom, E., and T. K. Ahn. 2008. The meaning of social capital and its link to collective action. Pages 17-35 in G. T. Svendsen and G. L. Svendsen, editors. Handbook of social capital: the troika of sociology, political science and economics. Edward Elgar, Northampton, Massachusetts, USA.

Patton, M. Q. 2003. Qualitative research and evaluation methods. Third edition. Sage, Thousand Oaks, California, USA.

Patulny, R. V., and G. L. H. Svendsen. 2007. Exploring the social capital grid: bonding, bridging, qualitative, quantitative. International Journal of Sociology and Social Policy 27(1/2):32-51. http://dx.doi.org/10.1108/01443330710722742

Plummer, R., D. R. Armitage, and R. C. de Loë. 2013. Adaptive comanagement and its relationship to environmental governance. Ecology and Society 18(1): 21. [online] URL: http://dx.doi. org/10.5751/ES-05383-180121

Plummer, R., and J. FitzGibbon. 2006. People matter: the importance of social capital in the co-management of natural resources. Natural Resources Forum 30(1):51-62. http://dx.doi. org/10.1111/j.1477-8947.2006.00157.x

Plummer, R., and J. FitzGibbon. 2007. Connecting adaptive comanagement, social learning and social capital through theory and practice. Pages 38-61 in D. Armitage, F. Birkes, and N. Doubleday, editors. Adaptive co-management: collaboration, learning, and multi-level governance. UBC Press, Vancouver, British Columbia, Canada.

Pokharel, B., and D. Paudel. 2005. Armed conflicts and community forest user groups in Nepal: can community forestry survive and contribute to peace building at the local level? ETFRN News 43-44:83-85.

Pretty, J. 2003. Social capital and the collective management of resources. Science 302:1912-1914. http://dx.doi.org/10.1126/ science. 1090847

Pretty, J., and D. Smith. 2004. Social capital in biodiversity conservation and management. Conservation biology 18 (3):631-638. http://dx.doi.org/10.1111/j.1523-1739.2004.00126.x

Pretty, J., and H. Ward. 2001. Social capital and the environment. World Development 29(2):209-227. http://dx.doi.org/10.1016/ S0305-750X(00)00098-X

Putnam, R. 1993. Making democracy work. Princeton University Press, Princeton, New Jersey, USA.
Putnam, R. D. 1998. Democracy in America at the end of the twentieth century. Pages 233-265 in D. Rueschemeyer, M. Rueschemeyer, and B. Wittrock, editors. Participation and democracy: east and west. Comparisons and interpretations. M.E. Sharpe, Armonk, New York, USA.

Röling, N. 2002. Beyond the aggregation of individual preferences: moving from multiple to distributed cognition in resource dilemmas. Pages 25-47 in C. Leeuwis and R. Pyburn, editors. Wheelbarrows full of frogs: social learning in rural resource management. Koninklijke Van Gorcum, Assen, The Netherlands.

Sanginga, P. C., R. N. Kamugisha, and A. M. Martin. 2007. The dynamics of social capital and conflict management in multiple resource regimes: a case of the southwestern highlands of Uganda. Ecology and Society 12(1): 6. [online] URL: http://www. ecologyandsociety.org/vol12/iss1/art6

Senge, P. M. 1990. The fifth disciple: the art and practice of the learning organization. Currency-Doubleday, New York, New York, USA.

Uphoff, N. 2000. Understanding social capital: learning from the analysis and experience of participation. Pages 215-249 in P. Dasgupta and I. Serageldin, editors. Social capital: a multifaceted perspective. The World Bank, Washington, D.C., USA.

Uphoff, N., and C. M. Wijayaratna. 2000. Demonstrated benefits from social capital: the productivity of farmer organizations in Gal Oya, Sri Lanka. World Development 28(11):1875-1890. http:// dx.doi.org/10.1016/S0305-750X(00)00063-2

Voß, J., and B. Bornemann. 2011. The politics of reflexive governance: challenges for designing adaptive management and transition management. Ecology and Society 16(2): 9. [online] URL: http://www.ecologyandsociety.org/vol16/iss2/art9/

Warner, M. 2000. Conflict management in community-based natural resource projects: experiences from Fiji and Papua New Guinea. ODI working paper 135. Overseas Development Institute, London, UK.

World Bank and Department for International Development (DFID). 2006. Unequal citizens: gender, caste and ethnic exclusion in Nepal. World Bank and DFID, Kathmandu, Nepal.

Yasmi, Y., H. Schanz, and A. Salim. 2006. Manifestation of conflict escalation in natural resource management. Environmental Science and Policy 9(6):538-546 http://dx.doi.org/10.1016/j. envsci.2006.04.003

Yin, R. K. 2009. Case study research: design and methods. Sage, Los Angeles, California, USA. 


\section{Appendix 1. Context}

\section{Socio-political landscape}

Nepal is highly diverse, with 125 social groups based on caste and ethnicity and 123 languages (CBS 2012). Political and economic power was consolidated historically in Nepal through the integration of the Hindu caste system into all aspects of society (World Bank and DFID 2006). Within this multi-layered system, members of Dalit groups (previously so-called "low caste" or "untouchable" people), such as Biswokarma and Damai, are perceived as holding the lowest positions and thus least symbolic and political power. There is a continuing correlation between caste and poverty and access to resources, despite the fact that caste-based discrimination was legally abolished in 1963 (World Bank and DFID 2006). In practice, social hierarchy in Nepal is multi-dimensional, shaped also by gender and ethnicity, as well as geopolitics, language and religion. In this context, people who are poor, female and/or Dalit or from some indigenous groups face considerable and overlapping socio-political barriers.

\section{Community forestry and livelihoods context}

Over $60 \%$ of Nepalis rely on integrated forest and agriculture systems for their livelihoods (CBS 2002). As well as providing slope stabilization, forests are a fundamental component of rural livelihood systems, for instance, providing food and bedding materials for livestock, wood for agricultural implements, and fuelwood. They are also a source of income generation for some households, through the sale of fuelwood, charcoal, wooden pots, and non-timber forest products.

Nepal has a large and well-established community forestry program. The program was catalyzed in the 1990s by international environmental concerns; over time it has evolved towards formal acknowledgement of livelihoods and equity. Today, over 17,000 Community Forestry User Groups (CFUGs) hold legal management and use rights to a total of 1,652,654 hectares of forest (Department of Forests [date unknown]). Community Forestry has emerged as a dynamic sphere in which a multitude of actors overtly and tacitly negotiate. The main actors include the CFUGs and their socio-ethnically diverse membership, district forest offices (and their subsidiary area forest offices and rangeposts), nongovernmental organizations, bilateral organizations, and participants in sectoral and multi-sectoral forums and networks. Moreover, the socio-political features of the community forestry landscape are in continual flux. CFUGs thus face an ongoing need to meet the changing demands of diverse actors, as well as to deal with uncertainties in knowledge, and adapt to evolving forest ecologies, environments, socio-political contexts, and markets (McDougall et al. 2008).

\section{Maoist insurgency and civil movement}

Nepal was home to a violent and widespread armed conflict between Maoist rebels and the government from the late 1990s to 2006. The services provided to CFUGs by the district forest offices - and, in some cases, by nongovernmental or bilateral agencies-came to a halt or were 
disrupted as offices were closed or even destroyed. In some cases CFUGs had to pay for "approval" (permission) from the Maoists' parallel administration. CFUG members were "requested", with varying degrees of pressure, to make donations to the Maoists and/or to listen to, sometimes multi-hour, "educational" speeches. CFUG members, as with rural Nepalis in general, were directly or indirectly affected by the violence, including being harmed or killed either intentionally or caught in the crossfire. Members of some CFUGs were judged by the rebels or their supporters to be elite, and thus threatened, harmed, or even killed; some relocated in fear. Fear and mistrust became widespread. Some CFUGs limited or stopped the harvesting of forest products for fear of encountering Maoists or army. Despite these disruptions, and at a time that various other levels of governance had all but ceased operating, many CFUGs did manage to continue to function at least at a low level-underscoring the significance of community forestry as one of Nepal's most resilient local democratic institutions (Pokharel and Paudel 2005).

A widespread civil pro-democracy movement grew in parallel with the Maoist insurrection. Its widely-supported protests played a key role in the monarchy's relinquishing of powers, the reinstatement of parliament, and subsequent democratic elections for a new constituent assembly, which reflected public demands for greater equity, transparency and accountability. 


\section{Appendix 2. Findings and analysis: Further evidence and examples}

\subsection{Networking: An increase in awareness of the potential value of networking}

During an initial community workshop about adaptive collaborative governance, leaders of three CFUGs were "quite ignited" when they realized that there were opportunities available that they had missed because they had not been linked to meso organizations. As one CFUG leader said "We did not know the importance of collaboration with external organizations. We have to move in a collaborative way onwards" (male CFUG Chairperson). Local awareness regarding the value of networking appeared to develop through experiencing networking in practice by means such as study visits and learning tours and through routine reflection on external relations as a part of the self-monitoring process. This awareness was supported by specific exercises during action planning by the members, including the identification of gaps and risks in their external relations.

Here we offer examples from the cases illustrating the four main forms of networking and collaborating that emerged:

- Increasing collaboration with local (community) institutions. For example, at one site the 2006 Assembly was jointly managed for the first time by a local children's club, a youth club, a women's group and the CFUG; the CFUG also collaborated with a women's group on culvert construction.

- CFUG-CFUG sharing. For example, several CFUGs asked their neighboring CFUG(s) to observe, share ideas, and give feedback for process or activity improvement.

- New involvement in meso (district or subdistrict) CFUG networks or forums (and, in one case, a multi-CFUG nontimber forest product enterprise), including involvement of marginalized members as representatives. At five sites where meso forums were or became quite active, meso actors began to visit the CFUGs more frequently and increasingly provide institutional, technical and regulatory support. In cases where the forums or networks were applying an adaptive collaborative governance approach themselves they specifically reflected on how to better connect with and meet CFUG needs.

- Pro-active expression of needs for information, resources or collaboration to outside agencies, and more regularly inviting outside actors to participate in or facilitate CFUG processes. Increasing numbers of marginalized members participated in trainings that emerged from these relationships, whereas prior to adaptive collaborative governance, elite members had accessed the majority of such opportunities.

\subsection{Changes in forest management, compliance, and condition as indicated by selfmonitoring}

The CFUG selfmonitoring records show that the CFUGs perceived forest management to have improved in 51 of 77 total relevant indicators between pre- and with-adaptive collaborative governance, compiled from all sites, while 26 out of the 77 stayed the same and none declined.

Among the 15 indicators created and monitored by the CFUGs (in total) relating to compliance with rules, 9 were assessed as improving and 6 as staying the same from the pre-adaptive collaborative governance to the adaptive collaborative governance period. 
The changes in forest management and compliance in the sites were likely influences in the locally-perceived changes in forest condition (including slope stabilization) identified in the CFUGs' self-monitoring records: 23 out of the CFUGs' 30 relevant indicators (compiled across all sites) indicated improvements in forest condition, 7 stayed the same, and none declined.

\subsection{Additional examples of joint actions viz-à-viz external actors}

At one site the chairperson disagreed with the CFUG's felling of some trees during road construction. Without discussion he reported this to the District Forest Officer (DFO) who initiated a revocation of the CFUG's forest rights. The chairperson then handed over all the CFUG's legal documents to the DFO without notifying the CFUG. When members learned of this, the executive, the road committee, and members went to the DFO to ask him to return the documents and reinstate their rights. After numerous discussions, the DFO agreed to do this, on the condition that each executive and road committee member pay a fine. The CFUG rejected this condition and threatened to complain to the regional forest office if the DFO persisted with this demand. In the face of this pressure, the DFO returned the fines and the chairperson resigned. The CFUG formed a new executive committee after the next general assembly, composed of six women and five men who had taken lead roles in this collective process. There was similar successful resistance at a different site, where members challenged a DFO's penalizing the CFUG for felling trees during fireline construction.

At another site, the CFUG applied the skills and procedures they had learned through adaptive collaborative governance to respond to a water issue. When a conflict arose regarding potential commercialization of the CFUG's water source by outside interests, the executive took the issue to the toles. The toles unanimously decided not to allow it because of its potential to cause a future community water shortage. The issue pulled the previously divided community together: "It was the first time that I have seen such a unity in our village. It is because we discussed the issues at toles" (male, CFUG Secretary).

\subsection{Intra-group relations and conflict management: selfmonitoring and extension}

As well as the improvements in conflict management presented in the text, the self-monitoring records of the CFUGs evidence related improvements in intra-group relations. Of the CFUGs that chose to explicitly monitor indicators of intra-group relations, including power and conflict, all recorded improvement: from the total of 11 indicators applied, all increased.

Moreover, some sites applied their learning about conflict management to other spheres. In one site for example, a tole leader emphasised to researchers that tole members had realized that the tole meetings were decreasing intra-tole conflict; this had stimulated a tole discussion about selfesteem and conflict. Members of the tole drew the lesson that tole members should maintain their and the tole's self-respect by members not shouting at each other during household or interhousehold conflicts so loudly that members of other toles could hear. Rather, the tole members agreed, conflict within households and in the tole should be addressed more calmly and systematically. Tole members indicated that this adjusted norm began to take root and that tole conflict subsequently decreased. 